\title{
Susceptibility of Cultivars to Biotic Stresses
}

\author{
Nino lannotta and Stefano Scalercio
}

Additional information is available at the end of the chapter

http://dx.doi.org/10.5772/52036

\section{Introduction}

The Italian history of crop protection has been dominated by the use of agrochemical, generally having a negative impact on the environment and residues in final products. The approach based on the use of genotypes with low susceptibility to biotic stresses searching for sources of resistances was largely uninvestigated for long time. Only recently researchers focussed their studies on this subject. Studies devoted to this subject are very difficult mainly for permanent crop such as the olive tree because time consuming and because it is very hard to compare the behaviour of a large germplasm in the same pedoclimatic condition. Furthermore, it is very hard to design tests of resistances under controlled conditions because of the difficulty due to the hard tolerance of captivity of pests such as olive fly and many others. In any case, recently research activities on this field has been greatly improved and several research projects are supported by many institutions.

On the other hand, abiotic stresses has been sufficiently studied, mainly for those concerning the cold tolerance. The CRA-OLI of Rende studied from fifteen years the behaviour of several cultivars in respect to the main biotic stresses utilising two large varietal collections planted in two experimental fields, the largest on the ionian coast of Calabria (Mirto-Crosia, Cosenza) and the smallest near Rende (Cosenza). Results showed a high behavioural diversity of observed cultivars showing different degree of susceptibility to main pathogens and phytofagous of the olive tree. Some cultivars has been deeply investigated searching for the mechanisms determining such behavioural differences.

\section{Susceptibility to biotic stresses}

Many studies reported in this paragraph have been carried out in two experimental olive groves 20-years old located in Calabria, South Italy, where hundreds of cultivars coming from around the world grow in the same pedoclimatic conditions and permitted us to produce useful data for comparing susceptibility to biotic stresses. 


\subsection{Susceptibility to Bactrocera oleae}

It is well known that cultivars have a differentiated susceptibility to olive fly infestations. In this paragraph are chronologically arranged some of papers devoted to the comparison of susceptibility of cultivars to the major insect pest of the olive. The cultivars Carboncella di Pianacce, Gentile, Bardhi i Tirana, Kokermadh i Berat and Nociara showed an infestation level significantly lower (less than 10\%) than the cultivars Carolea, Cassanese, Cucco, Giarraffa, Intosso, Kalinjot, Nocellara del Belice, Picholine and Santa Caterina (more than 20 \%) during two years of observations (1997-1998) (Iannotta et al., 2001) (Table 1). Other cultivars investigated by the same authors (Dritta di Moscufo, Leccino, Maiatica di Ferrandina and Mixan) showed intermediate infestation levels. Among these cultivars has been observed that cultivars showing a low infestation level had a higher percentage of sterile oviposition stings.

Iannotta et al. (2001) also underlined that the cultivars having a high amount of oleuropein in the pulp of drupes are those with the lowest level of infestation in the period considered optimal for the harvesting (end of October-beginning of November) (Table 1). In fact, the cultivars Carboncella di Pianacce, Gentile di Chieti, Bardhi i Tirana, Kokermadh i Berat and Nociara have an amount of oleuropein higher of $30 \mathrm{~g} / \mathrm{kg}$ of fresh pulp, while the cultivars with higher infestation level have an amount of oleuropein lower than $20 \mathrm{~g} / \mathrm{kg}$ of fresh pulp. From these data emerge a correlation between olive fly infestation and oleuropein content of drupes (Fig. 1).

\begin{tabular}{|l|cc|cc|c|}
\hline \multicolumn{1}{|c|}{ Cultivar } & $\begin{array}{c}\text { Sterile Oviposition } \\
\text { Stings } \\
(\%)\end{array}$ & \multicolumn{2}{c|}{ Infestation } & Oleuropein \\
& 27.5 & $\mathrm{C}$ & 8.5 & $\mathrm{~A}$ & (g/Kg f.p.) \\
\hline Bhardi i Tirana & 26.0 & $\mathrm{C}$ & 9.5 & $\mathrm{~A}$ & 36.60 \\
Carboncella di Pianacce & 13.0 & $\mathrm{AB}$ & 22.5 & $\mathrm{CDE}$ & 20.21 \\
Carolea & 17.0 & $\mathrm{ABC}$ & 24.5 & $\mathrm{E}$ & 16.12 \\
Cassanese & 23.5 & $\mathrm{ABC}$ & 26.5 & $\mathrm{E}$ & 19.11 \\
Cucco & 26.0 & $\mathrm{C}$ & 11.0 & $\mathrm{AB}$ & 18.51 \\
Dritta di Moscufo & 26.0 & $\mathrm{C}$ & 9.5 & $\mathrm{~A}$ & 31.37 \\
Gentile di Chieti & 16.5 & $\mathrm{AB}$ & 23.5 & $\mathrm{DE}$ & 10.81 \\
Giarraffa & 18.0 & $\mathrm{ABC}$ & 31.0 & $\mathrm{E}$ & 24.04 \\
Intosso & 12.5 & $\mathrm{~A}$ & 23.0 & $\mathrm{DE}$ & 9.29 \\
Kalinjot & 26.5 & $\mathrm{C}$ & 10.0 & $\mathrm{AB}$ & 31.18 \\
Kokermadh i Berat & 21.5 & $\mathrm{ABC}$ & 20.0 & $\mathrm{BCDE}$ & 29.01 \\
Leccino & 19.5 & $\mathrm{ABC}$ & 12.5 & $\mathrm{ABCD}$ & 27.88 \\
Maiatica di Ferrandina & 19.0 & $\mathrm{ABC}$ & 11.5 & $\mathrm{ABC}$ & 19.80 \\
Mixan & 18.5 & $\mathrm{ABC}$ & 23.0 & $\mathrm{DE}$ & 16.47 \\
Nocellara del Belice & 25.0 & $\mathrm{BC}$ & 9.5 & $\mathrm{~A}$ & 32.73 \\
Nociara & 17.0 & $\mathrm{ABC}$ & 24.0 & $\mathrm{E}$ & 19.58 \\
Picholine & 16.5 & $\mathrm{ABC}$ & 23.5 & $\mathrm{DE}$ & 16.83 \\
Santa Caterina & &
\end{tabular}

Table 1. Percentages of olive fly infestation showed by olive cultivars growing in the same pedoclimatic conditions. Letters indicate significant statistical differences ( $\mathrm{P}<0.01$; ANOVA test) (from Iannotta et al., 2001, modified). 


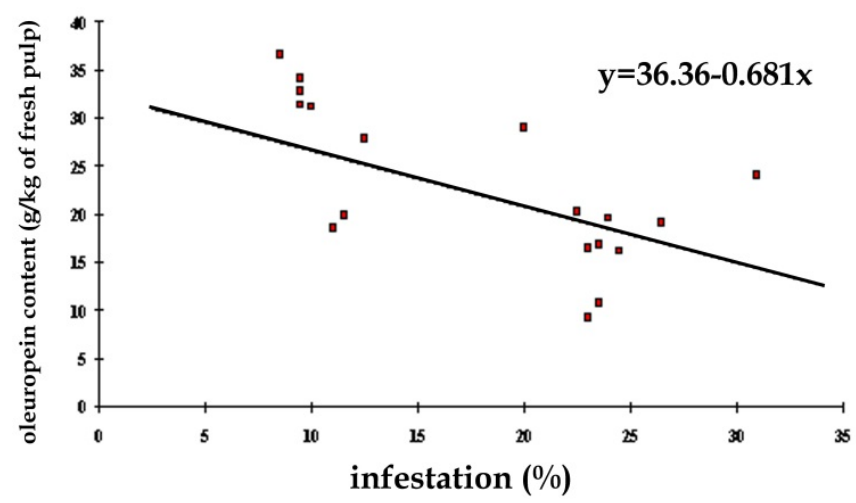

Figure 1. Correlation between oleuropein content of drupes and olive fly infestation (from Iannotta et al., 2001, modified).

Studies carried out in Sicily (Iannotta et al., 2002) highlighted the low susceptibility to olive fly infestations of the cv. Turdunazza antimosca compared to cvs. Tonda Iblea, Moresca and Verdese in the same olive grove. In this case, the low suceptibility of the cultivar Turdunazza antimosca seems to be related to the repellent action against the olive fly of that cultivar.

Iannotta et al. (2006a) observed a very low active infestation (percentage of drupes with living stages of the olive fly, such as eggs, larvae or pupae) rate along the ripening season for cvs. Cellina di Nardò and Cima di Mola, strongly reducing drupes damages and avoiding any kind of pesticide use for the production of a high quality olive oil (Table 2). The cv. Ogliarola del Vulture showed a low infestation level only until the end of October and this lead to an anticipated harvesting for producing a high quality olive oil without field pesticide applications. The $\mathrm{cv}$. Leccino registered a high infestation only during the first period of the olive ripening, while during October and November infestation was lower than the $20 \%$ (Table 2), i.e. tollerable for obtaining high quality olive oil. Other cultivars, mainly cv. Maurino, Moraiolo and Grossa di Spagna, showed a high susceptibility to olive fly attacks, showing active infestation levels higher than the $20 \%$. For last cultivars the field applications of pesticides are needed. Percentages of sterile oviposition stings were higher at the end of September for cultivars with low susceptibility, when the content of oleuropein within drupes is the highest of the ripening season. These results confirmed previous observations that demonstrated the role of oleuropein for increasing the mortality of eggs and reducing the hatching rate of young larvae (Iannotta et al., 2002).

These data underline that increasing studies on cultivar susceptibility could effectively produce significant results under a perspective of olive growing sustainability

Iannotta et al. (2006b) obtained results concerning 16 Italian cultivars (Table 3), displaying data concerning different development stages of the olive fly, active and total (active 
infestation plus exit holes of adults) infestation levels, detected amounts of oleuropein and cyanidine and weight of 100 drupes.

\begin{tabular}{|l|rc|cc|cc|}
\hline Cultivar & \multicolumn{2}{|c|}{$\begin{array}{c}\text { First } \\
\text { ripening period } \\
\mathbf{( \% )}\end{array}$} & $\begin{array}{c}\text { Second } \\
\text { ripening period } \\
\mathbf{( \% )}\end{array}$ & \multicolumn{2}{c|}{$\begin{array}{c}\text { Third } \\
\text { ripening period } \\
\text { (\%) }\end{array}$} \\
\hline Cellina di Nardò & 16,50 & $\mathrm{D}$ & 6,50 & $\mathrm{D}$ & 14,50 & $\mathrm{CD}$ \\
Cima di Mola & 22,00 & $\mathrm{BCD}$ & 15,50 & $\mathrm{CD}$ & 13,00 & $\mathrm{D}$ \\
Coratina & 49,00 & $\mathrm{ABC}$ & 79,50 & $\mathrm{~A}$ & 51,50 & $\mathrm{ABCD}$ \\
Dolce Agogia & 41,00 & $\mathrm{ABCD}$ & 20,50 & $\mathrm{CD}$ & 23,00 & $\mathrm{BCD}$ \\
Frantoio & 39,50 & $\mathrm{ABCD}$ & 35,00 & $\mathrm{BCD}$ & 45,00 & $\mathrm{ABCD}$ \\
Grossa di Spagna & 21,50 & $\mathrm{CD}$ & 16,50 & $\mathrm{CD}$ & 74,50 & $\mathrm{AB}$ \\
Leccino & 44,50 & $\mathrm{ABCD}$ & 15,00 & $\mathrm{CD}$ & 17,00 & $\mathrm{CD}$ \\
Maurino & 26,00 & $\mathrm{BCD}$ & 38,50 & $\mathrm{BCD}$ & 77,50 & $\mathrm{~A}$ \\
Moraiolo & 56,00 & $\mathrm{~A}$ & 49,50 & $\mathrm{ABC}$ & 65,00 & $\mathrm{ABC}$ \\
Ogliarola Barese & 32,00 & $\mathrm{ABCD}$ & 41,00 & $\mathrm{BCD}$ & 38,50 & $\mathrm{ABCD}$ \\
Ogliarola Vulture & 25,00 & $\mathrm{BCD}$ & 16,50 & $\mathrm{CD}$ & 71,00 & $\mathrm{AB}$ \\
Peranzana & 51,00 & $\mathrm{AB}$ & 66,00 & $\mathrm{AB}$ & 70,50 & $\mathrm{AB}$ \\
Pisciottana & 24,00 & $\mathrm{BCD}$ & 43,50 & $\mathrm{BC}$ & 53,00 & $\mathrm{ABCD}$ \\
\hline
\end{tabular}

Table 2. Active infestation trend. Letters indicate significant statistical differences $(\mathrm{P}<0.01 ; \mathrm{ANOVA}$ test), from Iannotta et al. (2006a), modified.

The same table shows that cvs. Ascolana tenera and Nostrana di Brisighella turn out to be significatively the less infested cultivars, both for active and total infestation in all observed ripening times. Cellina di Nardò shows the lowest susceptibility to olive fly attacks $(9.83 \%$ of active infestation and $17.67 \%$ of total infestation). Also cvs. Nera di Cantinelle, Frantoio, Tonda di Strongoli, Nolca, Cima di Melfi and Termite di Bitetto exhibit low susceptibility (active infestation lower than 13\%), while cvs. Dolce Agogia, Dolce di Rossano, Nostrale di Fiano Romano, Ogliarola del Bradano, Ogliarola garganica and Ogliarola del Vulture display intermediate susceptibility values. The active and total infestations, obtained as mean values for any cultivars concerning the different ripening times, turn out to be increasing during the season (Table 4).

The results obtained for 9 non-Italian cultivars show cvs. Gordal sevillana and Hojiblanca with the lowest level of active infestation $(<15 \%)$, cv. Konservolia the most infested and cvs. Arbequina, Kalamata, Koroneiki, Lucques, Manzanilla and Picual register intermediate infestation percentages (Table 5).

The results of Iannotta et al. (2006b) confirm a different behavior of olive cultivars concerning their susceptibility to olive fly attack. Investigated genotypes in the area of observation displayed a contained percentage of attack lower than $13 \%$ in the Italian cvs. Cellina di Nardò, Nera di Cantinelle, Frantoio, Tonda di Strongoli, Nolca, Cima di Melfi and Termite di Bitetto and lower than $15 \%$ in non-Italian cvs. Gordal sevillana and Hojiblanca. 
Active percentage within the limit of $15 \%$ is compatible with a high qualitative product (olive oil) avoiding the use of pesticides. It allows the achievement of the fixed aims, consisting in ecosystem and biocoenotic balances safeguard, which make economically positive the ecocultivation (organic and integrated farming).

\begin{tabular}{|c|c|c|c|c|c|c|c|}
\hline \multirow{2}{*}{$\begin{array}{c}\text { Weight } \\
100 \\
\text { drupes } \\
(\mathrm{g})\end{array}$} & \multirow{2}{*}{$\begin{array}{c}\text { Eggs } \\
\text { Fertile } \\
\text { (Aborted) }\end{array}$} & \multirow[b]{2}{*}{$\begin{array}{c}\text { Sterile } \\
\text { oviposition } \\
\text { stings }\end{array}$} & \multirow[b]{2}{*}{$\begin{array}{l}\text { Larvae } \\
\text { (pupae) }\end{array}$} & \multirow[b]{2}{*}{$\begin{array}{c}\text { Exit } \\
\text { holes }\end{array}$} & \multirow{2}{*}{ 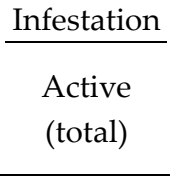 } & \multirow[b]{2}{*}{$\begin{array}{l}\text { Oleuropein } \\
\text { (ppm) }\end{array}$} & \multirow[b]{2}{*}{$\begin{array}{l}\text { Cyanidine } \\
\text { (ppm) }\end{array}$} \\
\hline & & & & & & & \\
\hline \multicolumn{8}{|c|}{ Ascolana tenera } \\
\hline 676.1 & $19.0(2.5)$ & 10.0 & $7.5(3.5)$ & 5.5 & $31.0(49.0)$ & 7974.1 & 0.0 \\
\hline 725.3 & $10.0(2.0)$ & 8.0 & $12.0(6.0)$ & 15.0 & $30.0(55.0)$ & 3595.4 & 17.1 \\
\hline 842.7 & $13.5(2.5)$ & 7.5 & $24.5(4.0)$ & 13.0 & $42.0(65.0)$ & 1419.0 & 129.3 \\
\hline \multicolumn{8}{|c|}{ Cellina di Nardò } \\
\hline 125.7 & $3.5(1.0)$ & 4.5 & $0.0(0.0)$ & 0.0 & $3.5(9.0)$ & 8165.2 & 79.0 \\
\hline 131.1 & $5.5(0.5)$ & 5.0 & $2.5(1.0)$ & 0.0 & $9.0(14.5)$ & 1482.1 & 1019.7 \\
\hline 143.3 & $2.0(2.5)$ & 3.5 & $12.5(2.5)$ & 6.5 & $17.0(29.5)$ & 0.0 & 1690.0 \\
\hline \multicolumn{8}{|c|}{ Cima di Melfi } \\
\hline 247.4 & $9.5(1.0)$ & 8.5 & $0.0(2.0)$ & 3.0 & $11.5(24.0)$ & - & - \\
\hline 271.0 & $11.5(5.0)$ & 17.0 & $0.0(0.0)$ & 4.5 & $11.5(38.0)$ & 2469.8 & 17.4 \\
\hline 260.8 & $5.5(4.0)$ & 10.0 & $4.5(3.5)$ & 6.0 & 13.5 (33.5) & 0.0 & 9.9 \\
\hline \multicolumn{8}{|c|}{ Dolce Agogia } \\
\hline 181.2 & $8.0(2.5)$ & 7.5 & $4.5(0.0)$ & 2.0 & $12.5(24.5)$ & 8919.3 & 27.3 \\
\hline 209.5 & $3.0(0.5)$ & 11.0 & $16.0(2.5)$ & 7.5 & $26.5(45.5)$ & 4889.6 & 0.0 \\
\hline 227.2 & $7.0(1.0)$ & 16.5 & $2.5(7.5)$ & 17.5 & $17.0(52.0)$ & 42.9 & 0.0 \\
\hline \multicolumn{8}{|c|}{ Dolce di Rossano } \\
\hline 133.7 & $7.0(2.0)$ & 13.5 & $3.0(2.0)$ & 0.0 & $12.0(27.5)$ & 11860.3 & 0.0 \\
\hline 186.6 & $4.0(0.5)$ & 6.5 & $8.0(0.5)$ & 3.5 & $12.5(23.0)$ & 681.7 & 96.7 \\
\hline 175.5 & $7.5(2.0)$ & 5.5 & $15.5(4.5)$ & 14.5 & $27.5(49.5)$ & 149.2 & 503.1 \\
\hline \multicolumn{8}{|l|}{ Frantoio } \\
\hline 157.6 & $6.5(3.0)$ & 9.0 & $0.0(0.0)$ & 0.0 & $6.5(18.5)$ & 7831.2 & 12.7 \\
\hline 175.3 & $6.0(0.0)$ & 9.5 & $3.0(0.0)$ & 1.0 & $9.0(19.5)$ & 1292.0 & 0.0 \\
\hline 221.4 & $5.0(0.5)$ & 3.5 & $7.5(4.5)$ & 2.0 & $17.0(23.0)$ & 561.4 & 0.0 \\
\hline \multicolumn{8}{|l|}{ Moraiolo } \\
\hline 163.6 & $8.0(2.5)$ & 5.5 & $3.5(0.0)$ & 0.5 & $11.5(20.0)$ & 11810.7 & 0.0 \\
\hline 183.0 & $13.0(4.0)$ & 5.5 & $0.5(3.0)$ & 1.0 & $16.5(27.0)$ & 5162.9 & 33.9 \\
\hline 231.2 & $5.5(0.5)$ & 8.5 & $12.0(4.5)$ & 5.0 & $22.5(36.5)$ & 1771.3 & 337.6 \\
\hline \multicolumn{8}{|c|}{ Nera di Cantinelle } \\
\hline 226.2 & $3.0(0.0)$ & 9.0 & $1.5(0.0)$ & 0.5 & $4.5(14.0)$ & 8727.3 & 10.5 \\
\hline 253.3 & $4.5(0.0)$ & 11.0 & $9.0(0.0)$ & 6.5 & $13.5(31.0)$ & 666.9 & 56.6 \\
\hline
\end{tabular}




\begin{tabular}{|c|c|c|c|c|c|c|c|}
\hline \multirow{2}{*}{$\begin{array}{c}\text { Weight } \\
100 \\
\text { drupes } \\
(\mathrm{g})\end{array}$} & \multirow{2}{*}{$\begin{array}{c}\text { Eggs } \\
\text { Fertile } \\
\text { (Aborted) }\end{array}$} & \multirow[b]{2}{*}{$\begin{array}{c}\text { Sterile } \\
\text { oviposition } \\
\text { stings }\end{array}$} & \multirow[b]{2}{*}{$\begin{array}{l}\text { Larvae } \\
\text { (pupae) }\end{array}$} & \multirow[b]{2}{*}{$\begin{array}{c}\text { Exit } \\
\text { holes }\end{array}$} & \multirow{2}{*}{ 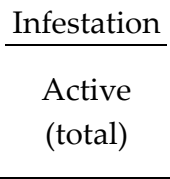 } & \multirow[b]{2}{*}{$\begin{array}{l}\text { Oleuropein } \\
\text { (ppm) }\end{array}$} & \multirow[b]{2}{*}{$\begin{array}{c}\text { Cyanidine } \\
\text { (ppm) }\end{array}$} \\
\hline & & & & & & & \\
\hline 270.9 & $4.0(0.0)$ & 6.5 & $7.5(2.5)$ & 16.5 & $14.0(37.0)$ & 39.1 & 210.1 \\
\hline \multicolumn{8}{|l|}{ Nolca } \\
\hline 250.2 & $1.0(0.0)$ & 13.0 & $2.5(0.5)$ & 2.5 & $4.0(19.5)$ & 155.9 & 91.1 \\
\hline 327.0 & $2.0(2.0)$ & 6.5 & $3.5(6.0)$ & 7.0 & $11.5(27.0)$ & 0.0 & 601.8 \\
\hline 325.1 & $2.0(2.0)$ & 8.0 & $13.5(5.0)$ & 10.0 & $21.0(41.0)$ & 0.0 & 1120.3 \\
\hline \multicolumn{8}{|c|}{ Nostrale di Fiano Romano } \\
\hline 255.5 & $10.5(2.0)$ & 10.5 & $3.5(3.5)$ & 12.0 & $17.5(42.0)$ & 3174.0 & 34.0 \\
\hline 262.4 & $7.0(1.5)$ & 8.0 & $6.0(3.5)$ & 8.5 & $19.0(37.0)$ & 463.4 & 25.4 \\
\hline 342.3 & $7.5(0.0)$ & 16.0 & $3.0(4.5)$ & 15.5 & $15.0(46.5)$ & 93.8 & 13.8 \\
\hline \multicolumn{8}{|c|}{ Nostrana di Brisighella } \\
\hline 481.7 & $13.5(2.5)$ & 10.5 & $12.5(8.0)$ & 5.0 & $36.0(54.0)$ & 6444.0 & 0.0 \\
\hline 801.2 & $3.5(0.5)$ & 0.0 & $5.0(6.5)$ & 19.5 & $22.0(42.0)$ & 5002.3 & 17.2 \\
\hline 674.9 & $15.5(2.0)$ & 6.5 & $15.5(8.0)$ & 29.5 & $39.0(77.0)$ & 454.0 & 0.0 \\
\hline \multicolumn{8}{|c|}{ Ogliarola del Bradano } \\
\hline 153.9 & $10.0(1.0)$ & 6.0 & $2.5(1.0)$ & 1.5 & $13.5(22.0)$ & 3830.2 & 0.0 \\
\hline 171.6 & $13.5(3.5)$ & 6.0 & $4.5(2.0)$ & 3.0 & $20.0(32.5)$ & 2238.0 & 0.0 \\
\hline 235.4 & $0.0(0.0)$ & 5.0 & $11.0(5.0)$ & 7.5 & $16.0(28.5)$ & 88.8 & 0.0 \\
\hline \multicolumn{8}{|c|}{ Ogliarola Garganica } \\
\hline 261.2 & $8.5(4.5)$ & 16.5 & $1.0(0.0)$ & 1.0 & $9.5(31.5)$ & 5387.2 & 71.6 \\
\hline 238.2 & $8.5(1.0)$ & 13.5 & $1.5(3.5)$ & 5.0 & $13.5(33.0)$ & 641.6 & 46.3 \\
\hline 250.6 & $2.5(1.0)$ & 4.0 & $10.0(5.0)$ & 13.5 & $20.5(39.0)$ & 444.0 & 705.6 \\
\hline \multicolumn{8}{|c|}{ Ogliarola del Vulture } \\
\hline 195.4 & $4.5(2.0)$ & 11.5 & $1.5(0.0)$ & 2.5 & $6.0(22.0)$ & 9082.3 & 36.9 \\
\hline 188.8 & $3.5(1.0)$ & 6.0 & $7.0(2.5)$ & 3.0 & $13.0(23.0)$ & 6669.3 & 21.4 \\
\hline 265.4 & $12.0(3.5)$ & 21.0 & $12.5(3.0)$ & 13.5 & $27.5(65.5)$ & 588.0 & 0.0 \\
\hline \multicolumn{8}{|c|}{ Termite di Bitetto } \\
\hline 228.0 & $4.5(0.0)$ & 8.0 & $4.5(0.0)$ & 1.5 & $9.0(18.5)$ & 1654.4 & 34.0 \\
\hline 268.8 & $2.0(0.0)$ & 6.5 & $10.0(0.0)$ & 14.0 & $12.0(32.5)$ & 345.6 & 513.5 \\
\hline 382.9 & $2.5(1.0)$ & 11.0 & $5.5(5.5)$ & 10.0 & $17.5(39.5)$ & 229.4 & 1647.1 \\
\hline \multicolumn{8}{|c|}{ Tonda di Strongoli } \\
\hline 389.7 & $7.5(1.0)$ & 7.0 & $1.0(1.0)$ & 2.0 & $9.5(19.5)$ & 8299.6 & 0.0 \\
\hline 448.7 & $8.5(0.0)$ & 11.0 & $3.0(0.0)$ & 1.0 & $11.5(23.5)$ & 4153.3 & 0.0 \\
\hline 453.3 & $2.5(0.5)$ & 6.5 & $7.0(4.0)$ & 10.5 & $13.5(31.0)$ & 557.1 & 15.5 \\
\hline
\end{tabular}

Table 3. Detailed data obtained in the different theses and ripening times concerning olive fly infestation and oleuropein and cyanidine drupe contents. For any cultivar, the observation was performed in three different ripening times (from Iannotta et al., 2006b, modified). 


\begin{tabular}{lccccc}
\hline Ripening time & $\begin{array}{c}\text { Active } \\
\text { infestation }\end{array}$ & Tukey test & $\begin{array}{c}\text { Total } \\
\text { infestation }\end{array}$ & Tukey test \\
\hline 26 Sept. 2006 & 12.38 & B & 28.81 & C & C \\
26 Oct. 2006 & 15.69 & B & 35.88 & b & B \\
29 Nov. 2006 & 21.28 & A & 49.06 & a & A \\
\hline
\end{tabular}

Table 4. Data concerning the comparison among the different investigated ripening times referred to Italian cultivars (from Iannotta et al., 2006b, modified). Letters indicate significant statistical differences (Capital letters: $\mathrm{P}<0.01$; small letters: $\mathrm{P}<0.05$; ANOVA test).

\begin{tabular}{|c|c|c|c|c|c|c|c|}
\hline $\begin{array}{c}\text { Weight } \\
\text { drupes } \\
(\mathrm{g})\end{array}$ & $\begin{array}{c}\text { Eggs } \\
\text { Fertile } \\
\text { (Aborted) }\end{array}$ & $\begin{array}{c}\text { Sterile } \\
\text { oviposition } \\
\text { stings }\end{array}$ & $\begin{array}{l}\text { Larvae } \\
\text { (pupae) }\end{array}$ & $\begin{array}{c}\text { Emergency } \\
\text { holes }\end{array}$ & $\begin{array}{c}\text { Infestation } \\
\begin{array}{c}\text { Active } \\
\text { (total) }\end{array}\end{array}$ & $\begin{array}{l}\text {-Oleuropein } \\
\text { (ppm) }\end{array}$ & $\begin{array}{c}\text { Cyanidine } \\
\text { (ppm) }\end{array}$ \\
\hline \multicolumn{8}{|l|}{ Arbequina } \\
\hline 149.6 & $11.5(1.0)$ & 9.5 & $2.5(0.0)$ & 1.0 & $14.0(25.5)$ & 508.9 & 11.5 \\
\hline 195.1 & $6.0(1.0)$ & 4.5 & $9.5(1.5)$ & 2.5 & $18.0(26.0)$ & 101.8 & 23.2 \\
\hline 191.0 & $5.5(0.0)$ & 5.0 & $7.5(3.0)$ & 14.0 & $16.0(35.0)$ & 1956.4 & 0.0 \\
\hline \multicolumn{8}{|c|}{ Gordal sevillana } \\
\hline 506.9 & $10.0(0.5)$ & 12.0 & $0.0(0.0)$ & 0.0 & $10.0(22.5)$ & 3994.2 & 17.6 \\
\hline 803.6 & $10.5(1.0)$ & 7.5 & $4.0(1.5)$ & 4.0 & $16.0(28.5)$ & 1764.8 & 77.7 \\
\hline 922.3 & $4.5(2.0)$ & 9.5 & $10(2.5)$ & 7.0 & $17.0(35.5)$ & 35.4 & 140.7 \\
\hline \multicolumn{8}{|l|}{ Hojiblanca } \\
\hline & & & $\begin{array}{c}1.5(0.0) \\
15.0\end{array}$ & & & & \\
\hline 219.6 & $2.0(3.0)$ & 11.5 & $(2.0)$ & 0.5 & $3.5(18.5)$ & 5808.2 & 0.0 \\
\hline 290.8 & $3.5(0.0)$ & 8.0 & 15.0 & 5.0 & $20.5(33.5)$ & 5424.5 & 187.5 \\
\hline 322.6 & $4.5(0.0)$ & 5.0 & (1.5) & 18.0 & $21.0(44.0)$ & - & - \\
\hline \multicolumn{8}{|l|}{ Kalamata } \\
\hline & & & $2.0(0.0)$ & & & & \\
\hline 197.9 & $11.5(3.5)$ & 14.0 & $6.5(3.5)$ & 1.0 & $13.5(32.0)$ & 10571.0 & 0.0 \\
\hline 298.3 & $5.0(1.0)$ & 0.0 & 11.5 & 2.5 & $15.0(18.5)$ & 3644.6 & 22.0 \\
\hline 301.0 & $11.0(2.0)$ & 1.0 & (6.5) & 3.0 & $29.0(35.0)$ & 240.7 & 0.0 \\
\hline \multicolumn{8}{|l|}{ Konservolia } \\
\hline & & & $2.5(0.0)$ & & & & \\
\hline 322.9 & $13.5(3.5)$ & 8.5 & $5.5(2.5)$ & 2.5 & $16.0(30.5)$ & 5761.2 & 187.5 \\
\hline 465.3 & $8.5(1.5)$ & 10.5 & 16.0 & 9.0 & $16.5(37.5)$ & 3203.6 & 122.0 \\
\hline 508.4 & $12.0(1.5)$ & 7.5 & (3.0) & 3.5 & $31.0(43.5)$ & 234.2 & 36.9 \\
\hline \multicolumn{8}{|l|}{ Koroneiki } \\
\hline & & & $\begin{array}{c}3.5(0.0) \\
10.0\end{array}$ & & & & \\
\hline 93.0 & $3.5(0.0)$ & 10.0 & (2.5) & 2.5 & $7.0(19.5)$ & 6987.9 & 0.0 \\
\hline 87.3 & $5.5(0.5)$ & 4.5 & 14.0 & 4.5 & $18.0(27.5)$ & 2029.9 & 0.0 \\
\hline 89.7 & $9.5(1.5)$ & 7.5 & (5.0) & 5.0 & $28.5(42.5)$ & 5774.4 & 0.0 \\
\hline
\end{tabular}


Olive Germplasm - The Olive Cultivation, Table Olive and Olive Oil Industry in Italy

\begin{tabular}{|c|c|c|c|c|c|c|c|}
\hline $\begin{array}{c}\text { Weight } \\
\text { drupes } \\
(\mathrm{g})\end{array}$ & $\begin{array}{c}\text { Eggs } \\
\text { Fertile } \\
\text { (Aborted) }\end{array}$ & $\begin{array}{c}\text { Sterile } \\
\text { oviposition } \\
\text { stings }\end{array}$ & $\begin{array}{c}\text { Larvae } \\
\text { (pupae) }\end{array}$ & $\begin{array}{c}\text { Emergency } \\
\text { holes }\end{array}$ & $\begin{array}{c}\text { Infestation } \\
\begin{array}{c}\text { Active } \\
\text { (total) }\end{array}\end{array}$ & $\begin{array}{l}\text { Oleuropein } \\
\quad(\mathrm{ppm})\end{array}$ & $\begin{array}{c}\text { Cyanidine } \\
(\mathrm{ppm})\end{array}$ \\
\hline \multicolumn{8}{|l|}{ Lucques } \\
\hline & & & $6.5(3.0)$ & & & & \\
\hline 515.7 & $6.0(1.5)$ & 0.0 & $6.5(5.5)$ & 5.0 & $15.5(22.0)$ & 3557.7 & 12.6 \\
\hline 623.9 & $2.0(0.0)$ & 12.0 & 12.5 & 6.5 & $14.0(32.5)$ & 2119.3 & 96.4 \\
\hline 853.3 & $5.0(0.0)$ & 5.5 & (3.0) & 13.5 & $20.5(39.5)$ & 0.0 & 12.4 \\
\hline \multicolumn{8}{|l|}{ Manzanilla } \\
\hline & & & $1.5(0.0)$ & & & & \\
\hline 376.3 & $11.5(2.5)$ & 5.5 & $7.5(2.5)$ & 3.0 & $13.0(24.0)$ & 10517.0 & 85.6 \\
\hline 353.2 & $5.0(1.0)$ & 9.0 & 18.0 & 6.0 & $15.0(31.0)$ & 6028.2 & 742.6 \\
\hline 423.8 & $5.5(1.5)$ & 55 & $(2.0)$ & 8.5 & $25.5(41.0)$ & 519.1 & 186.1 \\
\hline \multicolumn{8}{|l|}{ Picual } \\
\hline & & & $3.5(0.0)$ & & & & \\
\hline 364.5 & $8.0(1.5)$ & 14.0 & $\begin{array}{l}10.0 \\
(5.0)\end{array}$ & 0.0 & $11.5(27.0)$ & 8915.3 & 21.81 \\
\hline 435.1 & $6.5(2.5)$ & 1.0 & 17.5 & 6.0 & $21.5(31.0)$ & 5663.4 & 178.5 \\
\hline 507.1 & $4.5(2.0)$ & 3.5 & (1.5) & 7.0 & $23.5(36.0)$ & 2596.7 & 1695.6 \\
\hline
\end{tabular}

Table 5. Detailed percentages obtained in the different theses and ripening times concerning B. oleae infestation and oleuropein and cyanidine drupe contents. For any non-Italian cultivar, the observation was performed in three different ripening times (from Iannotta et al., 2006b, modified).

The susceptibility to B. oleae of other ten cultivars has been investigated by Iannotta et al. (2007a). Observations were carried out detecting the percentages of sterile oviposition stings, active infestation (presence of pre-imago stages: eggs, larvae and pupae) and total infestation (emergence holes, feeding tunnels and pre-imago stages) on olive fruit samples, 200 drupes per cultivar. Samples were collected in three different times during fruit ripening (Table 6).

\begin{tabular}{cccccc}
\hline \multirow{2}{*}{$\begin{array}{c}\text { Weight } \\
\text { drupes (g) }\end{array}$} & $\begin{array}{c}\text { Fertile } \\
\text { (Aborted) }\end{array}$ & $\begin{array}{c}\text { Sterile } \\
\text { stings }\end{array}$ & $\begin{array}{c}\text { Larvae } \\
\text { (pupae) }\end{array}$ & $\begin{array}{c}\text { Emergence } \\
\text { holes }\end{array}$ & Reinfested by \\
Bardhi Tirana & & & & & \\
309.69 & $9.5(2.0)$ & 9.0 & $0.5(0.0)$ & 0.5 & $0.0(0.0)$ \\
358.91 & $2.5(0.5)$ & 9.0 & $4.5(0.0)$ & 4.5 & $0.0(0.0)$ \\
415.48 & $7.5(1.0)$ & 6.0 & $12.5(1.0)$ & 7.0 & $2.5(0.0)$ \\
Carboncella di Pianacce & & & & \\
100.86 & $11.0(0.5)$ & 16.5 & $1.5(0.0)$ & 5.0 & $0.0(0.0)$ \\
128.96 & $9.5(0.5)$ & 9.5 & $11.0(5.5)$ & 9.5 & $0.0(0.0)$ \\
129.91 & $9.5(1.5)$ & 5.5 & $17.5(3.5)$ & 10.5 & $1.0(1.0)$ \\
Carolea & & & & & $0.0(0.0)$ \\
321.34 & $11.0(1.0)$ & 11.0 & $8.5(2.0)$ & 3.5 &
\end{tabular}




\begin{tabular}{|c|c|c|c|c|c|}
\hline \multirow{2}{*}{$\begin{array}{c}\text { Weight } \\
\text { drupes (g) }\end{array}$} & \multirow{2}{*}{$\begin{array}{c}\text { Eggs } \\
\text { Fertile } \\
\text { (Aborted) }\end{array}$} & \multirow{2}{*}{$\begin{array}{l}\text { Sterile } \\
\text { stings }\end{array}$} & \multirow{2}{*}{$\begin{array}{l}\text { Larvae } \\
\text { (pupae) }\end{array}$} & \multirow{2}{*}{$\begin{array}{c}\text { Emergence } \\
\text { holes }\end{array}$} & \multirow{2}{*}{$\begin{array}{c}\text { Reinfested by } \\
\text { Larvae (pupae) }\end{array}$} \\
\hline & & & & & \\
\hline 390.70 & $4.0(1.0)$ & 1.0 & $22.0(4.0)$ & 11.0 & $0.0(2.5)$ \\
\hline 463.46 & $1.0(1.0)$ & 5.5 & $18.0(5.5)$ & 21.5 & $9.0(2.0)$ \\
\hline \multicolumn{6}{|l|}{ Cassanese } \\
\hline 228.09 & $5.0(0.0)$ & 5.5 & $2.5(0.0)$ & 0.5 & $0.0(0.0)$ \\
\hline 285.48 & $8.5(0.5)$ & 3.0 & $13.5(0.0)$ & 7.0 & $0.5(1.0)$ \\
\hline 312.36 & $7.0(2.5)$ & 1.0 & $19.0(2.0)$ & 17.0 & $7.5(0.0)$ \\
\hline \multicolumn{6}{|l|}{ Gentile di Chieti } \\
\hline 511.35 & $14.0(0.5)$ & 19.0 & $4.0(0.0)$ & 5.0 & $0.0(0.0)$ \\
\hline 495.03 & $10.0(3.0)$ & 5.5 & $12.5(3.0)$ & 9.5 & $2.5(0.0)$ \\
\hline 524.06 & $6.5(0.0)$ & 7.0 & $14.5(1.0)$ & 12.0 & $4.0(0.0)$ \\
\hline \multicolumn{6}{|l|}{ Giarraffa } \\
\hline 606.61 & $5.0(0.5)$ & 15.0 & $6.0(0.0)$ & 8.0 & $0.0(0.0)$ \\
\hline 711.97 & $5.0(1.0)$ & 6.5 & $20.0(4.0)$ & 8.5 & $5.0(0.5)$ \\
\hline 771.70 & $2.5(0.0)$ & 2.0 & $23.0(6.0)$ & 17.5 & $12.0(0.0)$ \\
\hline \multicolumn{6}{|c|}{ Nocellara del Belice } \\
\hline 349.88 & $5.0(1.0)$ & 10.0 & $3.0(0.5)$ & 4.0 & $0.0(0.0)$ \\
\hline 408.33 & $0.5(1.0)$ & 3.0 & $20.5(5.0)$ & 10.0 & $8.0(2.5)$ \\
\hline 496.77 & $7.5(1.5)$ & 4.0 & $19.0(4.0)$ & 9.0 & $4.0(1.5)$ \\
\hline \multicolumn{6}{|l|}{ Nociara } \\
\hline 163.15 & $12.0(6.5)$ & 18.5 & $5.0(0.0)$ & 2.5 & $0.0(0.0)$ \\
\hline 196.58 & $5.5(0.0)$ & 5.5 & $20.0(3.0)$ & 10.0 & $4.0(0.0)$ \\
\hline 211.31 & $7.5(2.5)$ & 4.5 & $16.0(5.0)$ & 11.0 & $5.5(1.0)$ \\
\hline \multicolumn{6}{|l|}{ Picholine } \\
\hline 416.12 & $5.0(0.5)$ & 14.0 & $1.0(1.5)$ & 2.5 & $0.0(0.0)$ \\
\hline 422.25 & $6.5(0.5)$ & 5.5 & $13.0(1.5)$ & 13.5 & $4.0(0.0)$ \\
\hline 466.44 & $10.0(2.0)$ & 1.0 & $25.0(5.0)$ & 16.0 & $2.0(0.0)$ \\
\hline \multicolumn{6}{|c|}{ Tonda nera dolce } \\
\hline 242.92 & $2.0(0.5)$ & 3.5 & $0.0(0.0)$ & 0.0 & $0.0(0.0)$ \\
\hline 301.60 & $5.0(2.5)$ & 10.5 & $3.5(0.0)$ & 3.0 & $0.0(0.0)$ \\
\hline 298.97 & $4.0(0.5)$ & 12.5 & $4.0(0.0)$ & 3.5 & $0.0(0.0)$ \\
\hline
\end{tabular}

Table 6. Detailed percentages obtained in the different cultivars and ripening times concerning olive fly infestation (from Iannotta et al., 2007a). Observations were performed in three different ripening times (03rd October, 04th November and 5th December) for any investigated cultivar. Reported values are referred to 100 drupes.

Drupes weight increased during the season, according to the physiological processes involved in fruit maturation. Fertile eggs were more abundant than aborted ones, which did not exhibit a trend related to ripening times. For many observed cultivars, sterile oviposition stings were much more abundant in the first ripening time. Few pupae were registered within drupes in respect to larvae. As expected, emergence holes increased during the 
season showing a low value in the first ripening time. Very low value of reinfestation were observed according to female egg laying behavior.

Infestation values due to preimago stages seem to be generally related to the investigated ripening time rather than to the single investigated cultivar. More evident trends were determined by the olive plant phenology, however some cultivars showed an interesting and peculiar behavior in relation to attack levels of olive fly.

Results show that the less susceptible cultivars to B. oleae attacks are cvs. Tonda nera dolce and Bardhi Tirana while cvs. Carolea, Carboncella di Pianacce, Gentile di Chieti, Giarraffa, Nocellara del Belice, Nociara and Picholine displayed a considerable susceptibility (Table 6). The low susceptibility observed for cvs. Tonda nera dolce and Bardhi Tirana could be attributed to different causes. The high amount of oleuropein present in the drupes of Bardhi Tirana, according to previous studies (Iannotta et al., 2001; 2002; 2006a), could be involved in processes determining a low incidence of olive fly attack. It hasn't been observed an high presence of the glycoside in $\mathrm{cv}$. Tonda nera dolce while a considerable amount of cyanidine in the drupes was registered. The high value of cyanidine in cv. Tonda nera dolce could determine the observed low susceptibility. Probably, the dark color given by anthocyanins, achieved ever since in the early ripening stages, could confuse female olive flies in drupe recognition with a consequent decreased ovideposition.

The results obtained in the present research confirm those ones achieved in previous investigations, proving the need to explore the existent olive germplasm to search genetic resistance sources. It suggests the utility to achieve these results both to transfer directly to farmers' world and to emphasize ecosystem health and biodiversity conservation.

\subsection{Susceptibility to Pseudomonas savastanoi}

To keep under control the olive knot disease, the use of preventive measures turns out to be essential. Among these ones, the use of less susceptible cultivars emerged to be promising. Behavioural investigations showed a large variability in severities of olive disease caused by Pseudomonas savastanoi (Smith). A study carried out in the spring of 2005 by performing a large-scale investigations on the different responses to the pathogen of 262 Italian and 43 non-Italian cultivars, in the germplasm conservation field, where plants are cultivated under the same environmental and growing conditions (Iannotta et al., 2006c). The response to pathogen was evaluated by examining the symptomatology on the basis of the quantity of tubercles present on branches, arranged in classes of infection. During this time, several adverse meteorological events took place, including record minimum temperatures which influence the onset of the disease. Results displayed a different behaviour of olive cultivars to $P$. savastanoi in relation to their different susceptibility to the pathogen. Among observed Italian cultivars, $61 \%$ showed an infection's percentage ranging from 0 to $20 \%, 22.5 \%$ ranging from 20 to $40 \%, 11.1 \%$ ranging from 40 to $60 \%$, 5\% ranging from 60 to $80 \%$ and $0.4 \%$ ranging from 80 and $100 \%$. Among investigated cultivars, 86 displayed no symptom of disease (Abunara, Aitana, Ascolana dura, Ascolana semitenera, Aurina, Bianchera, 
Cacaredda, Capolga, Caprina Casalanguida, Caprina vastese, Carbonchia, Carpinetana, Cavalieri, Cellina Rotello, Colombina, Corneglia, Cornia, Corniola, Corniolo, Correggiolo, Dolce Andria, Fosco, Gentile Larino, Gentile Colletorto, Giusta, Gragnaro, Gragnan, Grappolo, Grossa Venafro, Grossale, I/77, Laurina, Lavagnina, Mantonica, Marina pugliese, Marzio, Minna di vacca, Morfa, Morchiaio, Morellona Grecia, Morinello, Nasitana, Nebbio Chieti, Nocellara etnea ovale, Ogliara, Ogliastro grande, Oliva grossa, Olivastra seggionese, Olivastro Bucchinico, Olivo da olio, Olivo della Madonna, Orbetana, Ortice, Pampagliosa, Pennulara, Piangente, Piantone Moiano, Pignola, Posola, Posolella, Precoce, Puntella, Racioppella, Rastellina, Raza, Razzo, Remugnana, Resciola Venafro, Romanella molisana, Rosciola coltodino, Rosciola Rotello, Rustica, Saligna, Sammartinara, Sammartinenga, San Benedetto, San Francesco, Santa Maria, Sperone di gallo, Tombarello, Tonda Alife, Tonda dolce, Tonda dolce Partanna, Tunnulidda, Vicio, Zinzifarica) and no cultivar with a percentage of infection equivalent to $100 \%$ was observed, emphasizing the presence of genetic resources in Italian germplasm for olive knot disease prevention. Among analysed non-Italian cultivars, $41.9 \%$ showed a percentage of infection included between 0 and $20 \%$, with 5 cultivars showing no sign of attack (Bardhi, Chetani, Hojiblanca, Lucques, Salonenque); $23.3 \%$ included between 20 and $40 \%$; $4.7 \%$ included between 40 and $60 \%$; $4.7 \%$ between 60 and $80 \% ; 23.3 \%$ included between 80 and 100\%. Cultivars Drobnica, Koroneiki and Vasilikada showed an infection equivalent to $100 \%$. This different susceptibility evaluated under the same agro-environmental conditions, confirms a different response to the pathogen in relation to the ratio plant/parasite and appears tightly dependent from cultivars tolerance to low temperatures.

\subsection{Susceptibility to Spilocaea oleagina}

The different susceptibility of olive cultivars to knot disease has been observed by several authors. Iannotta and Monardo (2004) observed that both percentage of the number of leaves infected and surface occupied on leaves by the symptoms of the disease are significantly different in observed cultivars. These authors observed that out of 35 cultivars studied cultivars Bardhi i Tirana, Carboncella di Pianacce, Cassanese, Dritta di Moscufo, Gentile di Chieti, Kalinjot and Leccino did not show any kind of symptoms of the disease, while cultivars Bosana, Carolea, Nocellara del Belice, Nera di Villacidro, Maiatica di Ferrandina, Itrana and Tonda di Cagliari were clearly infected by Spilocaea oleagina. The others observed cultivars showed intermediate values of the disease incidence (Table 7). The same authors related the cultivar susceptibility to the oleuropein content of leaves showing a direct relation between oleuropein content and cultivar susceptibility. In fact, low susceptible cultivars are those with the highest oleuropein content in leaves. Iannotta \& Monardo (2004) affirmed that oleuropein could play an important role in determining the development inhibition of the fungus within the leaves.

Results are similar to those obtained by Iannotta et al. (2001) concerning the relation among oleuropein content of drupes and susceptibility to olive fly infestation, demonstrating that studies devoted to the exploration of genetic variability of olive cultivars is a focal subject, to date not sufficiently developped but of great importance. 


\begin{tabular}{|c|c|c|c|c|c|c|}
\hline Cultivar & FI & & $\overrightarrow{\text { SI }}$ & & Oleurop & $(\mathrm{mg} / \mathrm{g})$ \\
\hline Ascolana & 0.80 & $\mathrm{BC}$ & 0.40 & B-E & 59.64 & $\mathrm{~B}-\mathrm{F}$ \\
\hline Bardhi i Tirana & 0.00 & C & 0.00 & E & 107.62 & $\mathrm{AB}$ \\
\hline Bosana & 39.20 & A & 13.60 & $\mathrm{~A}-\mathrm{C}$ & 43.69 & $\mathrm{DEF}$ \\
\hline Buscionetto & 2.50 & $A-C$ & 1.20 & B-E & 42.38 & DEF \\
\hline Carboncella & 0.00 & $\mathrm{C}$ & 0.00 & E & 86.31 & $\mathrm{ABC}$ \\
\hline Carolea & 8.30 & $\mathrm{~A}-\mathrm{C}$ & 12.80 & A-D & 44.62 & DEF \\
\hline Cassanese & 0.00 & C & 0.00 & $E$ & 60.45 & B-F \\
\hline Coratina & 1.70 & A-C & 2.70 & $A-E$ & 54.13 & $\mathrm{C}-\mathrm{F}$ \\
\hline Cucco & 2.50 & $\mathrm{~A}-\mathrm{C}$ & 1.50 & $A-E$ & 68.07 & B-F \\
\hline Dritta di Moscufo & 0.00 & $\mathrm{C}$ & 0.00 & E & 112.40 & A \\
\hline Gentile di Chieti & 0.00 & C & 0.00 & E & 79.82 & A-D \\
\hline Giarraffa & 4.20 & $\mathrm{~A}-\mathrm{C}$ & 1.90 & $A-E$ & 31.99 & $\mathrm{EF}$ \\
\hline Grossa di Spagna & 9.20 & A-C & 3.30 & $A-E$ & 68.67 & $A-E$ \\
\hline Intosso & 4.20 & $\mathrm{~A}-\mathrm{C}$ & 1.90 & $A-E$ & 66.02 & B-F \\
\hline Itrana & 26.70 & $\mathrm{~A}-\mathrm{C}$ & 17.10 & A & 54.99 & $\mathrm{C}-\mathrm{F}$ \\
\hline Kalinjot & 0.00 & $\mathrm{C}$ & 0.00 & E & 86.85 & A-D \\
\hline Leccino & 0.00 & C & 0.00 & E & 103.67 & $\mathrm{ABC}$ \\
\hline Maiatica di Ferran. & 27.50 & $A-C$ & 18.30 & A-B & 90.76 & $\mathrm{ABC}$ \\
\hline Mixan & 2.50 & $\mathrm{~A}-\mathrm{C}$ & 0.50 & $B-E$ & 74.73 & A-E \\
\hline Morghetana & 0.80 & $\mathrm{BC}$ & 0.10 & $C-E$ & 47.60 & DEF \\
\hline Nera di Gonnos & 10.00 & A-C & 2.80 & $A-E$ & 37.65 & DEF \\
\hline Nera di Villacidro & 29.20 & $\mathrm{~A}-\mathrm{C}$ & 16.00 & A-D & 48.67 & DEF \\
\hline Noc. del Belice & 32.50 & $\mathrm{AB}$ & 15.00 & A-B & 63.94 & A-F \\
\hline Noc. etnea & 3.30 & $\mathrm{~A}-\mathrm{C}$ & 1.70 & $A-E$ & 45.43 & DEF \\
\hline Noc. messinese & 4.20 & $\mathrm{~A}-\mathrm{C}$ & 1.10 & B-E & 37.60 & DEF \\
\hline Nostrale di Rigali & 13.30 & A-C & 7.90 & $B-E$ & 40.22 & DEF \\
\hline Passulunara & 4.20 & A-C & 1.20 & B-E & 63.76 & B-E \\
\hline Picholine & 4.20 & $\mathrm{~A}-\mathrm{C}$ & 2.10 & A-E & 65.78 & A-F \\
\hline Piddicuddara & 5.00 & $\mathrm{~A}-\mathrm{C}$ & 2.70 & $A-E$ & 70.11 & B-F \\
\hline Pizz'e Carroga & 11.70 & A-C & 4.40 & A-E & 73.77 & B-E \\
\hline S.Agostino & 5.00 & A-C & 3.20 & $A-E$ & 38.63 & DEF \\
\hline S.Caterina & 0.80 & $\mathrm{BC}$ & 2.10 & A-E & 42.33 & DEF \\
\hline Santagatese & 1.70 & A-C & 1.70 & $A-E$ & 80.82 & $A-E$ \\
\hline Tonda di Cagliari & 22.50 & A-C & 11.70 & $A-E$ & 47.87 & DEF \\
\hline Tonda iblea & 3.30 & $\mathrm{~A}-\mathrm{C}$ & 1.10 & B-E & 61.26 & B-F \\
\hline
\end{tabular}

Table 7. Percentage of infected leaves (FI\%) and percentage of surface occupied by symptoms on leave's surface (SI\%) of 35 cultivars (from Iannotta and Monardo, 2004). Letters indicate significant statistical differences $(\mathrm{P}<0.01$; ANOVA test).

\subsection{Susceptibility to Camarosporium dalmaticum}

Iannotta et al. (2006d) found a different level of susceptibility among cultivars for fruit rot disease. In particular, a low susceptibility was observed for cvs. Frantoio, Tonda di Strongoli and Dolce di Rossano. On the contrary, cvs. Ascolana tenera and Nostrana di Brisighella showed a high susceptibility (Table 8). Since the cultivars displaying the lowest susceptibility to the fungus are the same which show the lowest susceptibility to olive fly attacks, a direct correlation between could be hypotised. Also data concerning non-Italian cultivars show a different behaviour. In fact, cvs. Arbequina, Hojiblanca and Picual are the 
less infected and cv. Gordal sevillana the most affected by mycosis (Table 9). The study proves the utility of further investigations in order to characterize the different cultivars behaviour in relation to their parasites, so as to define their specific susceptibility.

\begin{tabular}{lcc}
\hline & \multicolumn{2}{c}{ C. dalmaticum } \\
\cline { 2 - 3 } Cultivar & Infection & LSD test \\
\hline Ascolana tenera & 12.00 & $\mathrm{~A}$ \\
Cellina di Nardò & 3.33 & $\mathrm{BC}$ \\
Cima di Melfi & 4.67 & $\mathrm{BC}$ \\
Dolce Agogia & 3.17 & $\mathrm{BC}$ \\
Dolce di Rossano & 1.67 & $\mathrm{BC}$ \\
Frantoio & 0.67 & $\mathrm{C}$ \\
Moraiolo & 4.00 & $\mathrm{BC}$ \\
Nera di Cantinelle & 3.17 & $\mathrm{BC}$ \\
Nolca & 4.33 & $\mathrm{BC}$ \\
Nostrale di Fiano Romano & 3.67 & $\mathrm{BC}$ \\
Nostrana di Brisighella & 11.17 & $\mathrm{~A}$ \\
Ogliarola del Bradano & 4.50 & $\mathrm{BC}$ \\
Ogliarola garganica & 2.83 & $\mathrm{BC}$ \\
Ogliarola del Vulture & 6.00 & $\mathrm{~B}$ \\
Termite di Bitetto & 3.67 & $\mathrm{BC}$ \\
Tonda di Strongoli & 1.50 & $\mathrm{BC}$ \\
\hline
\end{tabular}

Table 8. Mean values concerning $C$. dalmaticum infection referred to each Italian cultivars. Letters indicate significant statistical differences ( $\mathrm{P}<0.01$; ANOVA test). (from Iannotta et al., 2006d, modified).

\begin{tabular}{lcc}
\hline & \multicolumn{2}{c}{ C. dalmaticum } \\
\cline { 2 - 3 } Cultivar & Infection & LSD test \\
\hline Arbequina & 3.33 & $\mathrm{~b}$ \\
Gordal sevillana & 7.50 & $\mathrm{a}$ \\
Hojiblanca & 3.83 & $\mathrm{~b}$ \\
Kalamata & 5.00 & $\mathrm{ab}$ \\
Konservolia & 5.50 & $\mathrm{ab}$ \\
Koroneiki & 4.50 & $\mathrm{ab}$ \\
Lucques & 5.50 & $\mathrm{ab}$ \\
Manzanilla & 5.00 & $\mathrm{ab}$ \\
Picual & 3.00 & $\mathrm{~b}$ \\
\hline
\end{tabular}

Table 9. Mean values concerning $C$. dalmaticum infection referred to each non-Italian cultivars. Letters indicate significant statistical differences ( $\mathrm{P}<0.01$; ANOVA test). (from Iannotta et al., 2006d, modified).

Trials performed by Iannotta et al. (2007a) in the collection field of the CRA OLI compared susceptibility to Camarosporium dalmaticum of cultivars planted in the same environmental 
and agronomic conditions (Fig. 2). The investigation has been performed in 2005 by analyzing 10 cultivars, in the experimental olive plantation made up by a cultivar collection consisting in 20-years old plants. Observations were carried out detecting on 200 drupes per cultivar the infection level (\%) of C. dalmaticum by direct observation of drupes. Samples were collected in three different period during fruit ripening (03rd October, 04th November and 5th December).

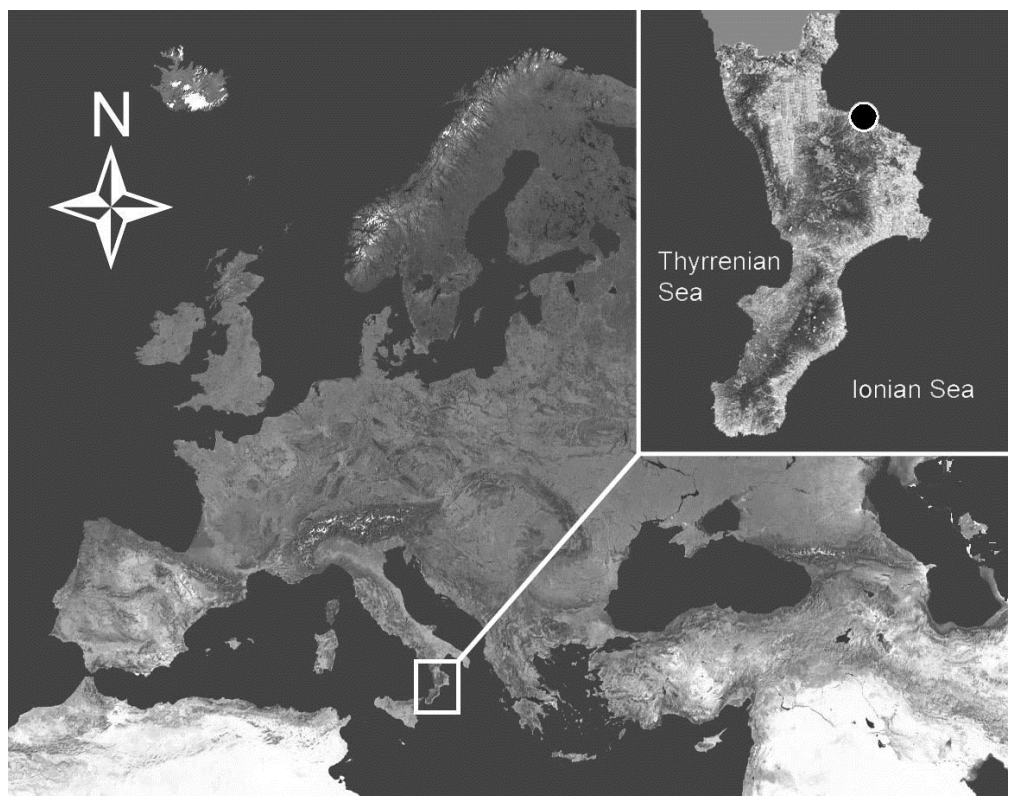

Figure 2. Location of CRA-OLI experimental field, where several cultivars are planted under the same agronomical and climatic conditions, on the ionian coast of Calabria (Mirto-Crosia, Cosenza, Italy).

\begin{tabular}{lll} 
& \multicolumn{2}{c}{ Infection } \\
\cline { 2 - 3 } \multicolumn{1}{c}{ Cultivar } & \multicolumn{1}{c}{ Mean* } & $S D$ \\
\hline Bardhi Tirana & $1.67^{D E}$ & 1.53 \\
Carboncella di & $1.33^{D E}$ & 2.31 \\
$\quad$ Pianacce & & \\
Carolea & $4.67^{A B}$ & 1.26 \\
Cassanese & $2.17^{B C D E}$ & 1.89 \\
Gentile di Chieti & $4.33^{A B C}$ & 1.61 \\
Giarraffa & $5.67^{A}$ & 1.04 \\
Nocellara del & $2.00^{C D E}$ & 2.29 \\
$\quad$ Belice & & \\
Nociara & $1.17^{D E}$ & 1.26 \\
Picholine & $3.17^{A B C D}$ & 1.53 \\
Tonda nera dolce & $0.58^{E}$ & 0.43 \\
\hline
\end{tabular}

Table 10. Mean infected drupes concerning Camarosporium dalmaticum infection. Letters indicate significant statistical differences ( $\mathrm{P}<0.01$; ANOVA test). (From Iannotta et al., 2007a, modified). 
Results display a different susceptibility of investigated genotypes in relation to the fungal infection, as indicated by significativity letters concerning analysis of variance (Table 10). The lowest susceptibility in relation to fungal infection has been observed for cv. Tonda nera dolce. Also cvs. Bardhi Tirana, Carboncella di Pianacce and Nociara showed a low susceptibility in relation to the pathogenic fungus infection. The cv. Giarraffa turn out to be the most susceptible cultivar while cvs. Carolea, Cassanese, Gentile di Chieti, Nocellara del Belice and Picholine display an intermediate susceptibility value. Comparison among investigated ripening times for pathogenic fungus emphasise an increase of infection percentages through the season.

\subsection{Resistance to Verticillium dahliae}

Verticillium wilt, caused by the fungus Verticillium dahliae Kleb., is a vascular wilt with a very large host range. Verticillium wilt is increasing in several Mediterranean countries, and it is very difficult to reduce its incidence because is not easy to apply in the field chemical compounds such as fosetyl-Al, directly inoculated within vascular system. Very little is known about biochemical and molecular mechanisms of olive resistance to the Verticillium wilt. Among investigated aspects, it seems to be very important the role of phenolic methabolism (Baidez et al., 2007; Markakis et al., 2010). Vizzarri et al. (2011) investigated the susceptibility of cvs. Arbequina, Arbosana, Frantoio, Ottobratica, Sant'Agostino and Urano by inoculating them with different isolates of Verticillium dahliae. Plantlets of 18 months and $160 \mathrm{~cm}$ high, has been inoculated by applying a small square of agar with sporulating fungal hyphae on wounded wood. After inoculation plantlets were observed for one year in a greenhouse. The severity of the disese was evaluated by utilising 5 classes of the percentage of damaged plant and the intensity of symptoms: $0 \%$, healthy plant; $20 \%$, plant with large clorosis and moderate foliar symptoms; $50 \%$, severe foliar symptoms and desiccation of vegetative apex; $75 \%$, desiccation of more than half of the plant; $100 \%$ dead plant, without defoliation (Colella et al., 2008). Furthermore, Vizzarri et al. (2011) defined a molecular protocol for studying the expression of gene involved in defense mechanisms of the olive. They utilised plants of 14 months of the $\mathrm{cv}$. Leccino, some artificially inoculated as described above and some non inoculated as negative control. Results showed that genetic resistance of tested cultivars, inoculated with different Verticillium isolates, is subordinated to the virulence of the inoculated isolate (Table 11).

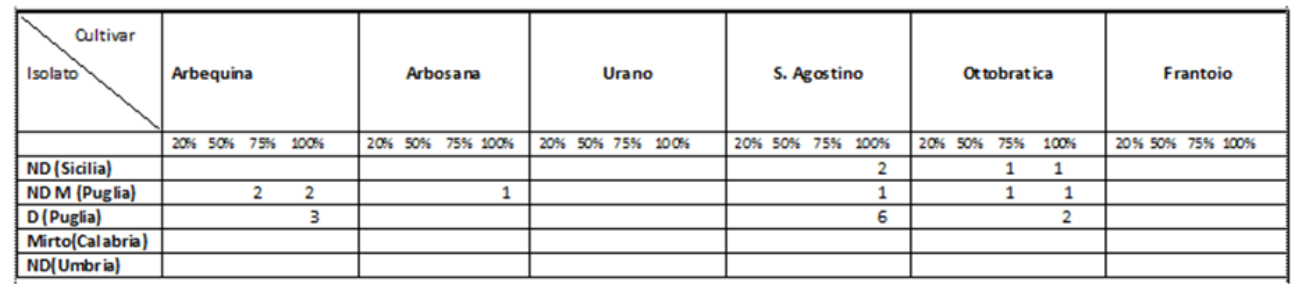

Table 11. Results of the genotypic susceptibility assay. Number of plants showing a given range of symptoms. Cultivars and isolates used (10 replicates for each cultivar). (from Vizzarri et al., 2011). 
The cv. Frantoio and Urano were the most resistant with no symptoms on tested plants, while cvs. Ottobratica and Sant'Agostino were higly susceptible. Further studies are needed for assessing the behaviour of cvs. Arbequina and Arbosana, largely utilised in superintensive olive plantations, that showed a differentiated susceptibility depending on the utilised isolate for inoculation.

Vizzarri et al. (2011) also tested a method for evaluating the expression of the genes ( $P A L$ and $C H S$ ) involved in defense mechanisms of olive. The level of trascript of these genes showed significant increments after plantlets wounding. Attaining the highest value 9 hours after plantlets wounding. Afterward, the level of transcript of both genes decrease, more evidently for the gene PAL after 24 hours, in any case maintaining high expression levels until 30 days after wounding (Fig. 3).

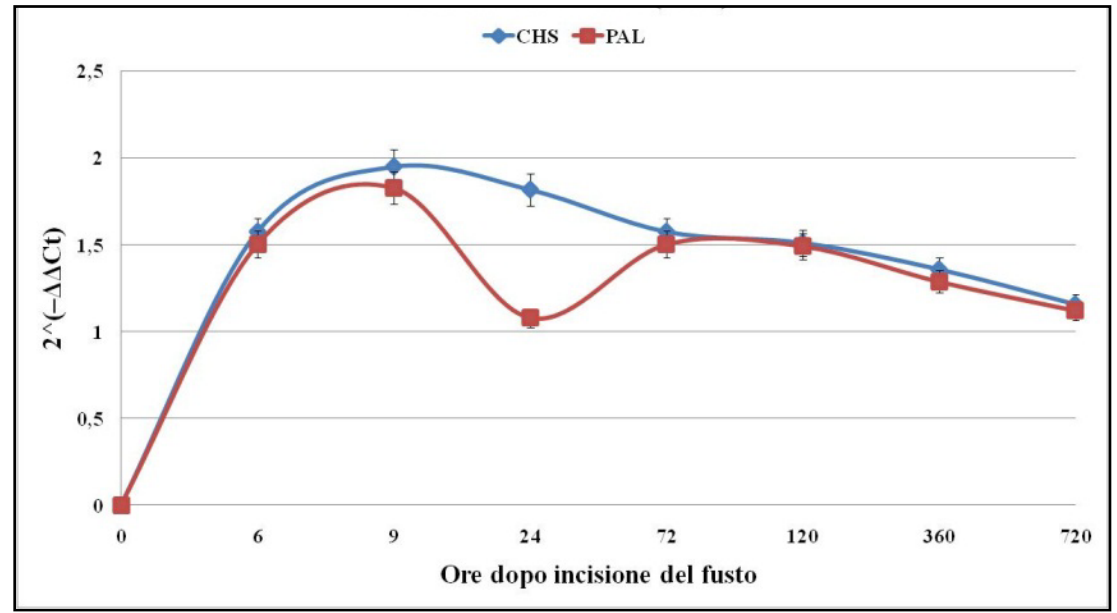

Figure 3. Time course of the relative transcript level of $P A L$ and $C H S$ genes in the leaves of stemwounded olive plantlets (cv. Leccino), as compared to unwounded plantlets (from Vizzarri et al., 2011).

The use oh this method permit to verify that the response of plant to the injury is quite rapid, more or less 9-12 hours. Vizzarri et al. (2011) hypothised that the evaluation of the expression level of genes $P A L$ e CHS for cultivars with different resistance could be important for verifying the role of phenolic methabolism in olive resistance to pathogenes. In fact, recent papers demonstrated that phenolic compounds are very important for modulating resistance/susceptibility of olive cultivars to verticillium wilt. Phenolic response to verticillium wilt is very different in resistant and susceptible cultivars. The resistant cv. Koroneiki showed higher increasing of phenols than susceptible cv. Amfissis when inoculated with verticillium wilt (Markakis et al., 2010). Genes PAL e CHS play an important role in the biosynthesis of phenolic compounds, then a role in determing resistance of olive cultivars to verticillium wilt could be hypothesised. 


\section{Factors affecting cultivar susceptibility}

Morphological parameters such as dimensions and coulor are known to be important in determining susceptibility of cultivars affecting female choice for laying eggs. Recently, a great effort is done for determining biochemical factors involved in resistance/susceptibility of olive cultivars to biotic stresses.

\subsection{The role of phenolic compounds}

Differences in the response of olive cultivars to olive fly infestations have been observed (Gümusay et al., 1990; Iannotta et al., 1999, 2006a, 2007a, 2007b; Pereira et al., 2004; Basile et al., 2006; Rizzo and Caleca, 2006; Daane and Johnson, 2010). Two phenolic compounds, oleuropein and cyanidine, were assessed to determine their role in the reduced susceptibility of certain olive cultivars to olive fly (Iannotta et al., 2006a, 2007a, 2007b). In addition, a positive correlation has been observed between the drupe oleuropein content and a low susceptibility of olive cultivars to olive fly damage such that when the drupe oleuropein content is high, the olive fruit is less susceptible to attack (Iannotta et al., 2006a, 2007a, 2007b).

\subsubsection{Oleuropein}

Iannotta et al. (2001) investigated the huge olive showing a low susceptibility to olive fly infestations of some cultivars due to the high content of oleuropein within drupes. That cultivars became particularly interesting in respect to cultivars having a low oleuropein content within drupes also when planted in the same environmental and agronomical conditions. Although a correlation between high oleuropein content and low susceptibility of olive cultivars to olive fly infestations is generally accepted, it is nopt clear the mechanism of action of this compound. Some authors hypothesised a mechanism of action against eggs and young larvae of olive fly explicated by oleuropein and their methabolites within the tissue of drupes, causing a reduction of the preimaginal population of this pest. Iannotta et al. (2001) evaluated the amount and the localisation of oleuropein within drupes of ten cultivars selected among them known as low-susceptible and high-susceptible ones. Furthermore, absolute oleuropein has been applied directly on the oviposition sting in order to evaluate its efficacy to control egg hatchling and the following larval development. Results confirm the different behaviour of tested cultivars with cvs. Bardhi i Tirana, Carboncella di Pianacce, Gentile di Chieti and Nociara less susceptible than cvs. Carolea, Nocellara del Belice, Giarraffa, Cucco, Picholine and Cassanese (Table 12). Susceptibility of cultivars is correlated to the amount of oleuropein within drupes. Furthermore, the amount of oleuropein is higher where female lays eggs. The higher amount of this compound in the epicarp found for the low susceptible cultivars seems to be related to genetic characteristics of cultivars more than to phisiological response to olive fle attacks, as demonstrated by comparing the distribution of oleuropein in healthy and infested drupes. 


\begin{tabular}{|c|c|c|c|c|c|}
\hline Cultivar & $\begin{array}{c}\text { Active } \\
\text { infestation } \\
(\%)\end{array}$ & $\begin{array}{c}\text { Sterile } \\
\text { oviposition } \\
\text { stings } \\
(\%)\end{array}$ & $\begin{array}{l}\text { Oleuropein } \\
\text { (drupe) } \\
(\mathrm{mg} / \mathrm{g})\end{array}$ & $\begin{array}{c}\text { Oleuropein } \\
\text { (epicarp) } \\
\text { (mg/g) }\end{array}$ & $\begin{array}{c}\text { Oleuropeina } \\
\text { (mesocarp) } \\
(\mathrm{mg} / \mathrm{g})\end{array}$ \\
\hline Bardhi i Tirana & $8,5 \mathrm{~A}$ & $27,5 \mathrm{C}$ & $29,60 \mathrm{~cd}$ & 32,89 & 26,48 \\
\hline $\begin{array}{l}\text { Carboncella di } \\
\text { Pianacce }\end{array}$ & $9,5 \mathrm{~A}$ & $26,0 \mathrm{C}$ & $60,04 b$ & 70,54 & 49,55 \\
\hline Gentile di Chieti & $9,6 \mathrm{~A}$ & $26,4 \mathrm{C}$ & $38,82 b c$ & 37,69 & 39,96 \\
\hline Nociara & $8,9 \mathrm{~A}$ & $25,2 \mathrm{BC}$ & $91,91 \mathrm{a}$ & 141,37 & 42,45 \\
\hline Carolea & $22,7 \mathrm{CDE}$ & $13,8 \mathrm{AB}$ & $2,25 \mathrm{~cd}$ & 23,90 & 20,61 \\
\hline Nocellara del Belice & $23,1 \mathrm{DE}$ & $18,6 \mathrm{ABC}$ & $40,52 b c$ & 48,93 & 32,12 \\
\hline Giarraffa & $23,6 \mathrm{DE}$ & $16,5 \mathrm{AB}$ & $11,41 d$ & 13,05 & 9,78 \\
\hline Cucco & $26,8 \mathrm{E}$ & $23,5 \mathrm{ABC}$ & $21,10 \mathrm{~cd}$ & 23,24 & 18,87 \\
\hline Picholine & $24,1 \mathrm{E}$ & $17,1 \mathrm{ABC}$ & $18,80 \mathrm{~cd}$ & 17,36 & 20,25 \\
\hline Cassanese & $27,4 \mathrm{E}$ & $16,9 \mathrm{ABC}$ & $14,30 \mathrm{~d}$ & 17,24 & 11,36 \\
\hline
\end{tabular}

Table 12. Detailed percentages obtained in the different cultivars concerning olive fly infestation (from Iannotta et al., 2001, modified). Reported values are referred to 100 drupes. Letters indicate significant statistical differences $(\mathrm{P}<0.01$; ANOVA test).

The use of oleuropein directly on oviposition stings confirm the role of control agent of this compound. After ten days from the oleuropein application, within treated sample only the $31 \%$ of olive were infested, while within the untreated sample the infested olive were the $65 \%$.

Phenolic composition and concentration are related to genetic features of a given olive cultivar. These genetic features can be used as varietal markers and as indicators of fruit maturation (Esti et al., 1998). Furthermore, a correlation between olive fruit size and oleuropein content has been shown. Small-fruit cultivars are characterised by high oleuropein content (Amiot et al. 1986). Phenolic compounds are important for the defence of plants against pathogens and insect infestations (Haukioja et al., 1985; Hudgins et al., 2003). The antimicrobial activity of phenolic compounds is well documented (Bisignano et al. 1999; Rauha et al., 2000; Proestos et al., 2005; Pereira et al., 2006, 2007).

It has been shown that oleuropein and cyanidine contents are inversely related. During olive fruit maturation the oleuropein content decreases rapidly (Limiroli et al., 1995) while flavonoid content as cyanidine increases (Amiot et al., 1989). In detail, olive fruit maturation consists of three phases: the growth, green maturation and black maturation (Amiot et al., 1989). While in the growth phase an accumulation of oleuropein occurs, in the green maturation phase it decreases. The black maturation phase is characterized by the appearance of anthocyanins and by the progressive decrease of oleuropein levels (Amiot et al., 1989). In Iannotta et al. (2006a) the mean content of both phenolic compounds appears genetically determined. Similar results were observed by Iannotta et al. (2007a, 2007b) confirming a different olive genotype behavior which depends on the genetically determined content of phenolic compounds (Esti et al., 1998). Moreover, the oleuropein 
content of drupes is not affected by B. oleae attacks, as it is not moved to the damage site. No differences in the oleuropein content were observed between non-infested and infested drupes belonging to the same cultivar (Iannotta et al., 2002).

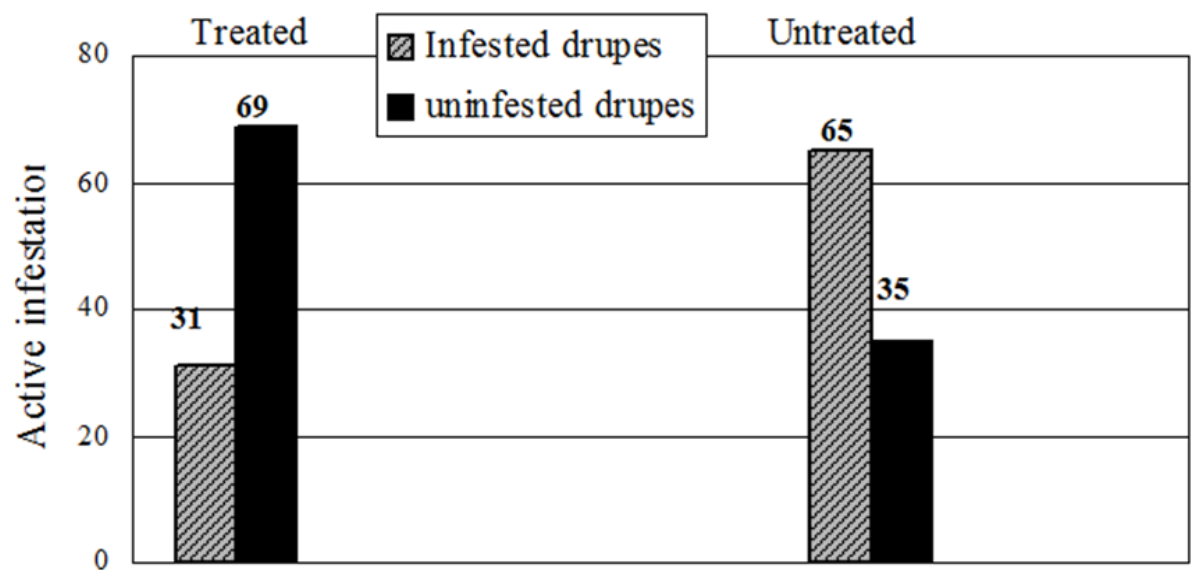

Figure 4. Results of treatment test with oleuropein of oviposition stings (from Iannotta et al., 2001, modified).

In previous studies, it has been established that the drupe oleuropein content is genetically determined since it hasn't been observed a statically significative difference between oleuropein content in non infested and infested drupes by B. oleae belonging to the same genotype (Iannotta et al., 2001). Moreover, it has been proved that the differences in oleuropein amounts are correlated to the different behavior of the cultivars in relation to olive fly attacks (Iannotta et al., 2001, 2002, 2006b).

Oleuropein was first isolated from olive leaves (Panizzi et al., 1960) where it is present in high levels (Le Tutour and Guedon, 1992). In addition, it occurs throughout the tree and in any constituent part of the fruit (Servili et al., 1999). Oleuropein confers resistance to diseases and to insect infestation of the olive tree (Soler-Rivas et al., 2000). The bactericidal and bacteriostatic activities of oleuropein and its degradation products against many pathogenic microorganisms have been investigated (Hirschman, 1972; Federici and Bongi, 1983) and its in vitro activity has been detected in relation to several bacteria, fungi, viruses, and parasitic protozoans (Hirschman, 1972; Walter et al., 1973; Gourama and Bullerman, 1987; Tassou et al., 1991; Tranter et al., 1993; Tassou and Nychas, 1994, 1995). Oleuropein can also interfere with the synthesis of virus amino acids, prevent viral shedding, budding or assembly at the cell membrane, inhibit viral replication and, in the case of retroviruses, neutralize the production of reverse transcriptase and proteases. Oleuropein is also able to stimulate phagocytosis, as a response of the immune system against pathogenic microorganisms (Hirschman, 1972). A strong chemotactile repulsion exerted by oleuropein in the oviposition of olive fly eggs has been described (Soler-Rivas et al., 2000). Small droplets of olive sap exuded just after oviposition prevent other females from ovipositing on 
the same fruit (Girolami et al., 1981; Lo Scalzo et al., 1994). Oleuropein acts by inhibiting the development of olive fly immature stages, especially eggs and first instar larvae during the early ripening period (Iannotta et al., 2002). The higher concentration of oleuropein in the epicarp than in the mesocarp may be due to the biological function of oleuropein in drupe protection against pests (Soler-Rivas et al., 2000). In fact, the epicarp is the interface between the outer environment and the inner olive fruit. Therefore, high levels of oleuropein in the epicarp protect the fruit against olive fly ovideposition (Iannotta et al., 2002).

Moreover, the defence response of fruits damaged both by pathogens and mechanical means, is mediated by $\beta$-glucosidase; this enzyme hydrolyses the oleuropein, producing highly reactive aldehyde molecules. Olive cultivars with different levels of enzyme activity have differing degrees of susceptibility to the olive fly. This may be related to the ability of the $\beta$-glucosidase to produce highly reactive aldehyde molecules in damaged tissues. A strong peroxidase activity is thereafter detected as a consequence of damage (Spadafora et al., 2008). Results obtained by Iannotta et al. (2001) showed that five cultivars (Bardhi i Tirana, Carboncella di Pianacce, Gentile di Chieti, Kokermadh i Berat, and Nociara) with high levels of drupe oleuropein $\left(31.18-36.60 \mathrm{~g} \mathrm{~kg}^{-1}\right)$ had low levels of infestation (lower than $10 \%$ ). When oleuropein content decreases, a corresponding increase in the amount of damage caused by olive flies occurs. In the same cultivars, Iannotta et al. (2001) found that the percentage of sterile oviposition stings ranged from 25.0 to $27.5 \%$. Similar results were also observed for cultivars Sant'Agostino, Leccino, and partially Frantoio (Basile et al., 2006). Sterile sting numbers and oleuropein content are inversely proportional to infestation (Iannotta et al., 2001). The role of oleuropein in the inhibition of the development of olive fly immature stages has been shown by performing a comparison between untreated olive samples and samples treated with oleuropein belonging to the $\mathrm{cv}$. Carolea. The cultivar Carolea was chosen because it is susceptible to the olive fly. After ten days, infestation levels were $31 \%$ and $65 \%$, respectively, in the oleuropein-treated and non-treated samples (Iannotta et al. 2002). The concentration of oleuropein is greater in the epicarp rather than in the mesocarp during the entire ripening process, except in the case of cvs. Gentile di Chieti and Picholine (Iannotta et al., 2002, 2007a). In these varieties, there is a slightly lower content of oleuropein in the epicarp during the early ripening period. In another study no correlation was observed between infestation and oleuropein content (Iannotta et al., 2006a). In fact, olive fly infestation may be different on the same olive cultivar under different environmental conditions (Fontanazza, 2000) inasmuch as the oleuropein content might be affected by climatic trend (Iannotta et al., 2006a). In a study performed in 2005 in an experimental field located on the Ionian coast of Calabria (Southern Italy), it was observed that cv Cellina di Nardò was the least infested by the olive fly in terms of total infestation (17.67\%). In contrast, cvs. Ascolana tenera and Nostrana di Brisighella were the most damaged attaining percentages of total infestation at $56.33 \%$ and $57.67 \%$, respectively (Iannotta et al., 2006a). This difference is presumably related also to fruit size (Daane and Johnson, 2010). In fact, Cellina di Nardò has relatively small fruits compared to Ascolana tenera and Nostrana di Brisighella. In addition, it has been shown that small-fruit cultivars 
are characterised by high oleuropein content (Amiot et al., 1986), playing a synergic role in determining low susceptibility.

Interestingly, it has also been observed that many cultivars characterized by low susceptibility to olive fly attacks showed low susceptibility to the fungal pathogen Spilocaea oleagina (Cast.) Hugh. and a negative correlation between oleuropein content in olive leaves and fungal infection has been found (Iannotta and Monardo, 2004). In addition, a correlation between B. oleae infestation and Camarosporium dalmaticum (Thüm.) Zachos \& Tzav.-Klon. infection has been established (Iannotta et al., 2007d). Since the same cultivars showed low levels of susceptibility to both parasites, it could be assumed that high levels of oleuropein may play a role also in determining low cultivar susceptibility to fungal disease (Iannotta et al., 2006c, 2007a).

\subsubsection{Cyanidine}

Cyanidine occurs in olive fruits (Servili et al., 1999) and an increase of cyanidine content at the end of the maturation stages of the olive fruit, as a consequence of hydrolytic processes, was found (Vinha et al., 2005). On the reasons of different genotype behavior concerning the susceptibility to olive fly attacks, the direct influence of cyanidine in the drupes could be, in effect, supposed. It is evident in cvs. Cellina di Nardò, Nolca and Termite di Bitetto which register high value of cyanidine, increasing during the season (Iannotta et al., 2006b). When investigated genotypes are cultivated in the same pedoclimatic conditions and samples obtained from them are collected in the same ripening times, it is possible attribute the differences, concerning cyanidine amount, to a strong influence of the different investigated genotypes genetic diversity. It has been observed that the completely pigmented drupes are not very recognizable by $B$. oleae females determining considerable difficulties for their ovideposition (Caleca, pers. comm.).

A role played by cyanidine in resistance to herbivores was additionally assessed (Harborne and Williams, 1998). Significant differences were found among cultivars in relation to active and total infestations and cyanidine content (Iannotta et al., 2006a). Cultivars Ascolana tenera and Nostrana di Brisighella had the highest level of active infestation $(34.33 \%$ and $32.33 \%$, respectively) while cv. Cellina di Nardò was the least infested (9.83\%). In addition, cvs. Frantoio, Gordal sevillana, Koroneiki, Nera di Cantinelle, Nolca, Ogliarola garganica, and Tonda di Strongoli showed low levels of susceptibility to olive fly (lower than 15\%). Cultivars Cellina di Nardò, Nolca, and Termite di Bitetto had higher levels of cyanidine than other cultivars in the study and had low levels of infestation.

In a study undertaken in 2005 in an experimental field located on the Ionian coast of Calabria (Southern Italy), Iannotta et al. (2007a) found the lowest susceptibility to olive fly attack for cvs Tonda nera dolce and Bardhi i Tirana (6.67\% and $13.50 \%$, respectively). On the contrary, cvs. Carolea, Cassanese, Carboncella di Pianacce, Gentile di Chieti, Giarraffa, Nocellara del Belice, Nociara and Picholine were susceptible with a mean percentage of active infestation ranging from 22.17 to $29.83 \%$. The presence of cyanidine in the first 
ripening period only for $\mathrm{cv}$. Tonda nera dolce suggests a possible role in determining the lowest level of active infestation observed.

Studies on cultivars Bardhi i Tirana, Carolea and Tonda nera dolce (Iannotta et al., 2007a) corroborate results obtained in previous investigations. Cultivars Bardhi i Tirana and Carolea were selected because they have low and high levels of susceptibility, respectively, to olive fly whilst cultivar Tonda nera dolce was selected because it shows high levels of cyanidine. Differences were found among the three cultivars in relation to active and total infestations and oleuropein and cyanidine contents. The lowest percentages of active and total infestations were observed on $\mathrm{cv}$. Tonda nera dolce $(8.62 \%$ and 20.12 , respectively), while cv. Carolea had the most damage (29.00\% and $49.38 \%$, respectively). Cultivar Bardhi i Tirana showed intermediate values of active and total infestations. The low susceptibility found for cv Bardhi i Tirana, although greater than the susceptibility showed by cv Tonda nera dolce, might be due to the highest oleuropein content observed. The content of cyanidine in cv. Tonda nera dolce might be responsible for the lowest susceptibility found.

Cyanidine probably acts by giving olive fruits a dark colour during the early ripening stages. This may confuse female olive flies in drupe recognition resulting in a decrease in oviposition. This hypothesis is supported by the evidence that in herbivorous diurnal insects, visual cues may play an important role in the location of host plants and essential resources, such as food, mating, and oviposition sites (Prokopy and Owens 1983). This situation is very common for frugivorous Tephritid flies that feed and oviposit on fruits (Katsoyannos, 1989; Fletcher and Prokopy, 1991; Diaz-Fleischer et al., 2000; Prokopy and Papaj, 2000). A laboratory experiment investigating the effect of fruit colour on attracting olive fruit fly females was carried out by Katsoyannos et al. (1985). In this study, females were left to select for oviposition sites among hollow, hemispheric, ceresin wax domes of different colours. Yellow and orange domes were preferred for oviposition compared to domes of other colours. Red, blue, black, and white domes were the least preferred. Red, blue, and black correspond to the colour of ripening olives reached during the maturation stages. Fruit colour is genetically determined in some cultivars and is related to the content of anthocyanins. Olive fly females prefer green olives for oviposition compared to red and black olives (Cirio, 1971; Rizzo and Caleca, 2006).

The high content of phenolic compounds found in several cultivars is a resource in olive germplasm. Field researches demonstrated that a high content of phenolic compounds is related to low susceptibility to olive fly attacks and other parasites. Therefore, the planting of genotypes containing high amounts of these compounds may greatly contribute to a significant reduction of pesticides inputs. In addition, the presence of phenolic compounds in olive fruits is also associated with various benefits for human health deriving from high quality olive oil intake. Therefore, the conservation of olive intraspecific biodiversity preserves sources of genetic resistance to various pests. To preserve olive germplasm biodiversity in accordance with CAP directives and minimize pesticide use diversifying agronomic practices are strongly related. Strategic B. oleae control is thus a priority for safeguarding both environmental integrity and consumer health. The identification of genetic 
resistance sources may represent an effective means for olive crop management. In fact, using olive cultivars with low susceptibility to olive fly may represent an effective strategy for organic and integrated pest management, eliminating or decreasing pesticides inputs.

\section{Author details}

Nino Iannotta and Stefano Scalercio

Agricultural Research Council - Olive Growing and Oil Industry Research Centre, Rende (CS), Italy

\section{Acknowledgement}

We thanks Veronica Vizzarri, Tiziana Belfiore, Maria Elena Noce, Luigi Perri and all the other colleagues involved in field and laboratory works and that allow us to write this contribute. Financial support was provided by the Italian Ministry of Agriculture, Food and Forestry Policy through the project GERMOLI "Salvaguardia e valorizzazione del GERMoplasma OLIvicolo delle collezioni del CRA-OLI"

\section{References}

Amiot, M.J.; Fleuriet, A. \& Macheix, J.J. (1986). Importance and evolution of phenolic compounds in olive during growth and maturation. Journal of Agricultural and Food Chemistry, Vol.34, pp. 823-826.

Amiot, M.-J.; Fleuriet, A. \& Macheix, J.-J. (1989). Accumulation of oleuropein derivatives during olive maturation. Phytochemistry, Vol.28, pp. 67-69.

Baidez, A.G.; Gomez, P.; Del Rio, J.A. \& Ortuno, A. (2007). Disfunctionality of the xylem in Olea europaea L. plants associated with the infection process by Verticillium dahliae Kleb. role of phenolic compounds in plant defense mechanism. Journal of Agricultural and Food Chemistry, Vol.55, pp. 3373-3377.

Basile, B.; Romano, R.; Garonna, A.P.; Forlani, M. \& Rao, R. (2006). Preliminary study of the susceptibility of different olive cultivars to olive fruit fly [Bactrocera oleae (Gmel.)]. Proceedings of the Second International Seminar on "Biotechnology and Quality of Olive tree Products around the Mediterranean basin", Olivebioteq, Marsala-Mazara del Vallo 5-10 November 2006, Vol. II: 319-322.

Bisignano, G.; Tomaino, A.; Lo Cascio, R.; Crisafi, G.; Uccella, N. \& Saija, A. (1999). On the in vitro antimicrobial activity of oleuropein and hydroxytyrosol. J. Pharm. Phrmacol., Vol.51, pp. 971-974.

Cirio, U. (1971). Reperti sul meccanismo stimolo-risposta nell'ovideposizione del Dacus oleae Gmelin (Diptera, trypetidae). Redia, Vol.52, pp. 577-600.

Colella, C.; Miacola, C.; Amenduni, M.; D’Amico, M.; Bubici, G. \& Cirulli, M. (2008). Sources of verticillium wilt resistence in wild olive germplasm from the Mediterranean region. Plant Pathology, Vol. 57, pp. 533-539.

Daane, K.M. \& Johnson, M.W. (2010). Olive fruit fly: managing an ancient pest in modern times. Annual Review of Entomology, Vol.55, pp. 151-169. 
Díaz-Fleischer, F., Papaj, D.R., Prokopy, R.J., Norrbom, A.L. \& Aluja, M. (2000). Evolution of fruit fly oviposition behavior, in M. Aluja \& A.L. Norrbom (eds.), Fruit flies (Diptera: Tephritidae): Phylogeny and evolution of behavior, CRC Press, Boca Raton, pp. 811-841.

Esti, M.; Cinquanta, L. \& La Notte, E. (1998). Phenolic compounds in different olive varieties. Journal of Agricultural and Food Chemistry, Vol.46, pp.32-35.

Federici, E. \& Bongi, G. (1983). Improved method for isolation of bacterial inhibitors from oleuropein hydrolysis. Appl. Environ. Microbiol., Vol.46, pp. 509-510.

Fletcher, B.S. \& Prokopy, R.J. (1991). Host location oviposition in tephritid fruit flies, in A.A. VV., Reproductive behaviour of Insects: Individuals and Populations, Chapman and Hall, London, pp. 139-171.

Fontanazza, G. (2000). Olivicoltura intensiva meccanizzata, Edagricole, Bologna, Italy.

Girolami, V.; Vianello, A.; Strapazzon, A.; Ragazzi, E. \& Veronese, G. (1981). Ovipositional deterrents in Dacus oleae. Ent. Exp. Appl., Vol.29, pp. 177-188.

Gourama, H. \& Bullerman, L.B. (1987). Effects of oleuropein on growth and aflatoxin production by Aspergillus parasiticus. Lebensm. -Wiss. u. Techn., Vol.23, p. 226.

Gümusay, B.; Özilbey, U.; Ertem, G. \& Oktar, A. (1990). Studies on the susceptibility of some important table and oil olive cultivars of Aegean region to olive fly (Dacus oleaea Gmel.) in Turkey. Acta Horticulturae, Vol.286, pp. 359-362.

Harborne, J.B. \& Williams, C.A. (1998). Anthocyanins and other flavonoids. Natural Product Reports, Vol.15, pp. 631-652.

Haukioja, E.; Suomela, J. \& Neuvonen, S. (1985). Long-term inducible resistance in birch foliage: triggering cues and efficacy on a defoliator. Oecologia, Vol.65, pp. 363-369

Hirschman, S.Z. (1972). Inactivation of DNA polymerases of murine leukaemia viruses by calcium elenolate. Nat. New Biol., Vol.238, pp. 277-279.

Hudgins, J.W.; Christiansen, E. \& Franceschi, V.R. (2003). Methyl jasmonate induces changes mimicking anatomical defenses in diverse members of the Pinaceae. Tree Physiol., Vol.23, pp. 361-371.

Iannotta, N.; Perri, L.; Tocci, C. \& Zaffina, F. (1999). The behaviour of different olive cultivars following attacks by Bactrocera oleae (Gmel.). Acta Horticulturae, Vol.474, pp. 545-548

Iannotta, N.; Monardo, D.; Perri, E. \& Perri, L. (2001). Comportamento di diverse cultivar di olivo nei confronti degli attacchi di Bactrocera oleae (Gmel.) e correlazione con la quantità di oleuropeina presente nelle drupe, Atti Convegno "Biodiversità e sistemi ecocompatibili", Caserta, 2001, pp. 649-653.

Iannotta, N.; Monardo, D. \& Perri, L. (2002). Relazione tra contenuto e localizzazione dell'oleuropeina nella drupa e attacco di Bactrocera oleae (Gmel.), Atti Convegno Internazionale di Olivicoltura. Spoleto, 2002, pp. 361-366.

Iannotta, N. \& Monardo, D. (2004). Suscettibilità di cultivar di olivo a Spilocaea oleagina (Cast.) Hugh. e correlazione con il contenuto di oleuropeina nelle foglie. Conv. "Germoplasma Olivicoli e tipicità dell'olio", Perugia 5 dicembre 2003, pp. 216-220.

Iannotta, N.; Condello, L.; Perri, L. \& Belfiore, T. (2006a). Valutazione di suscettibilità di genotipi di olivo nei confronti di Bactrocera oleae (Gmel.). Italus Hortus, Vol.13 (2), pp. 242-245.

Iannotta, N.; Macchione, B.; Noce, M.E.; Perri, E. \& Scalercio, S. (2006b). Olive genotypes susceptibility to the Bactrocera oleae (Gmel.) infestation. Proceedings of the Second International 
Seminar on "Biotechnology and Quality of Olive tree Products around the Mediterranean basin", Olivebioteq, Marsala-Mazara del Vallo 5-10 November 2006, Vol. II: 261-266.

Iannotta, N.; Noce, M.E.; Scalercio, S. \& Vizzarri, V. (2006c). Behaviour of olive cultivars towards the knot disease caused by Pseudomonas savastanoi. Journal of Plant Pathology, 88 (3, Special Issue), S45.

Iannotta, N.; Noce, M.E.; Perri, L.; Scalercio, S. \& Vizzarri, V. (2006d). Susceptibility of olive cultivars to the Camarosporium dalmaticum (Thüm) infections. Proceedings of the Second International Seminar on "Biotechnology and Quality of Olive tree Products around the Mediterranean basin", Olivebioteq, Marsala-Mazara del Vallo 5-10 November 2006, Vol. II: 311-314.

Iannotta, N.; Noce, M.E.; Ripa, V.; Scalercio, S. \& Vizzarri, V. (2007a). Assessment of susceptibility of olive cultivars to the Bactrocera oleae (Gmel.) and Camarosporium dalmaticum (Thüm.) Zachos \& Tzav.-Klon. attacks in Calabria. Journal of Environmental Science and Health, Part B, Vol.42, pp. 789-793.

Iannotta, N.; Belfiore, T.; Monardo, D.; Noce, M.E.; Scalercio, S. \& Vizzarri, V. (2007b). Indagine nel germoplasma dell'olivo sul comportamento di numerosi genotipi in relazione alla loro suscettibilità agli attacchi parassitari. Acta Biologica, Vol.83, pp. 215-220.

Katsoyannos, B.I. (1989). Field responses of Mediterranean fruit flies to spheres of different color patterns and to yellow crossed panels, in R. Cavalloro (ed.), Fruit flies of Economic Importance, Balkema, Rome, Italy, pp. 393-400.

Katsoyannos, B.I.; Patsouras, G. \& Vrekoussi, M. (1985). Effect of colour hue and brightness of artificial oviposition substrates on the selection of oviposition sites of Dacus oleae. Entomol. Exp. Appl., Vol.38(3), pp. 205-214.

Le Tutour, B. \& Guedon, D. (1992). Antioxidative activities of Olea europea leaves and related phenolic compounds. Phytochemistry, Vol.31, pp. 1173-1178.

Limiroli, R.; Consonni, R.; Ottolina, G.; Marsilio, V.; Bianchi, G. \& Zetta, L. (1995). 1H and 13C NMR Characterization of new Oleuropein Aglycones. J. Chem. Soc., Perkin Trans. 1, Vol.1, pp. 1519-1523.

Lo Scalzo, R.; Scarpati, M.L.; Verzengnassi, B. \& Vita, G. (1994). Olea europaea chemical repellent to Dacus oleae females. J. Chem. Ecol., Vol.20, pp. 1813-1823.

Markakis, E.A.; Tjamos, S.E.; Antoniou, P.P.; Roussos, P.A.; Paplomatas, E.J. \& Tjamos, E.C. (2010) . Phenolic responses of resistant and susceptible olive cultivars induced by defoliating and nondefoliating Verticillium dahliae pathotypes. Plant Disease, Vol.94 (9), pp. 1156-1162.

Panizzi, L.; Scarpati, M.L. \& Oriente, E.G. (1960). Structure of oleuropein, bitter glycoside with hypotensive action of olive oil. Note II. Gazz. Chim. Ital., Vol.90, pp. 1449-1485.

Pereira, J.A.; Alves, M.R.; Casal, S. \& Oliveira, M.B.P.P. (2004). Effect of olive fruit fly infestation on the quality of olive oil from cultivars Cobrançosa, Madural and Verdeal Transmontana. Ital. J. Food Sci., Vol.16, pp. 355-365.

Pereira, J.A.; Pereira, A.P.G.; Ferreira, I.C.F.R.; Valentão, P.; Andrade, P.B.; Seabra, R.; Estevinho, L. \& Bento, A. (2006). Table olives from Portugal: phenolic compounds, antioxidant potential and antimicrobial activity. J. Agric. Food Chem., Vol.54, pp. 8425-8431.

Pereira, J.A.; Oliveira, I.; Sousa, A.; Valentao, P.; Andrade, P.B.; Ferreira, I.C.F.R.; Ferreres, F.; Bento, A.; Seabra, R. \& Estevinho, L. (2007). Walnut (Juglans regia L.) leaves: Phenolic compounds, antibacterial activity and antioxidant potential of different cultivars. Food and Chemical Toxicology, Vol.45, pp. 2287-2295. 
Proestos, C.; Chorianopoulos, N., Nychas, G.J. \& Komaitis, M. (2005). RP-HPLC analysis of the phenolic compounds of plant extracts investigation of their antioxidant capacity and antimicrobial activity. J. Agric. Food Chem., Vol.53, pp. 1190-1195.

Prokopy, R.J. and Owens, E.D. (1983). Visual detection of plants by herbivorous insects. Ann. Rev. Entomol., Vol.28, pp. 337-64.

Prokopy, R.J. and Papaj, D.R. (2000). Behavior of flies of the genera Rhagoletis, Zonosemata, and Carpomya (Trypetinae: Carpomyina), in M. Aluja and A.L. Norrbom (eds.), Fruit flies (Tephritidae): phylogeny and evolution of behavior, CRC, Boca Raton, FL., pp. 219-252.

Rauha, J.P.; Remes, S.; Heinonen, M.; Hopia, A.; Kähkönen, M.; Kujala, T.; Pihlaja, K.; Vuorela, H. \& Vuorela, P. (2000). Antimicrobial effects of Finnish plant extracts containing flavonoids and other phenolic compounds. Int. J. Food Microbiol., Vol.56, pp. 3-12.

Rizzo, R. \& Caleca, V. (2006). Resistance to the attack of Bactrocera oleae (Gmelin) of some Sicilian olive cultivars. Proceedings of the Second International Seminar on "Biotechnology and Quality of Olive tree Products around the Mediterranean basin", Olivebioteq, MarsalaMazara del Vallo 5-10 November 2006, Vol. II: 291-298.

Servili, M.; Baldioli, M.; Mariotti, F. \& Montedoro, GF. (1999). Phenolic composition of olive fruit and virgin olive oil: distribution in the constitutive parts of fruit and evolution during oil mechanical extraction process. Acta Horticulturae, Vol.474, pp. 609-619.

Soler-Rivas, C.; Espin, J.C. \& Wichers, H.J. (2000). An easy and fast test to compare total free radical scavenger capacity of foodstuffs. Phytochem. Anal., Vol.11, pp. 330-338.

Spadafora, A.; Mazzuca, S.; Chiappetta, F.; Parise, A.; Perri, E. \& Innocenti, A.M. (2008). Oleuropein-specific-b-glucosidase marks early response of olive fruit (Olea europaea) to mimed insect attack. Agricultural sciences in China, Vol.7, pp. 703-712.

Tassou, C.; Nychas, G.J.E. \& Board, R.G. (1991). Effect of phenolic compound and oleuropein on the germination of Bacillus cereus T-spores. Biotechnol. Appl. Biochem., Vol.13, pp. 231-237.

Tassou, C. \& Nychas, G.J.E. (1994). Inhibition of Staphylococcus aureus by Olive phenolics in broth and in Food Model System. Journal of Food Protection, Vol.57, pp. 120-124.

Tassou, C. \& Nychas G.J.E. (1995). Inhibition of Salmonella enteritidis by oleuropein in broth and in a model Food system. Letters in Applied Microbiology, Vol.20, pp. 120-124

Tranter, H.S.; Tassou, S.C. \& Nychas, G.J. (1993). The effect of the olive phenolic compound, oleuropein, on growth and enterotoxin B production by Staphilococcus aureus. J. Appl. Bacteriol., Vol.74, pp. 253-259.

Vinha, A.F.; Ferres, F.; Silva, B.M.; Valentão, P.; Gonçalves, A.; Pereira, J.A.; Oliveira, M.B.; Seabra, R.M. \& Andrade, P.B. (2005). Phenolic profiles of Portuguese olive fruits (Olea europaea L.): Influences of cultivar and geographical origin. Food Chemistry, Vol.89, pp. 561-568.

Vizzarri, V.; Ferrara, M.; Salimonti, A.; Zelasco, S.; Iannotta, N.; Santilli, E.; Perri, E. \&Nigro, F. (2011). Studio della resistenza di genotipi di olivo a Verticillium dahliae kleb. e relativa risposta della pianta. Acta Italus Hortus, in press.

Walter, W.M.Jr.; Fleming, H.P. \& Etchells, J.L. (1973). Preparation of antimicrobial compounds by hydrolysis of oleuropein from green olives. Appl. Microbiol., Vol.26, pp. 773-776. 